\title{
Complement dysregulation and disease: from genes and proteins to diagnostics and drugs.
}

Santiago Rodriguez de Cordoba ${ }^{1, \#}$, Agustin Tortajada, ${ }^{1}$, Claire L Harris ${ }^{2}$ and B Paul Morgan 2,\#

1) Centro de Investigaciones Biológicas, Consejo Superior de Investigaciones Científicas and Centro de Investigación Biomédica en Enfermedades Raras, Ramiro de Maeztu 9, 28040 Madrid, Spain.

2) Institute of Infection \& Immunity, School of Medicine, Cardiff University, Cardiff, CF14 4XN, UK.

\#) Co-corresponding authors:

Santiago Rodriguez de Cordoba (srdecordoba@cib.csic.es)

B Paul Morgan (morganBP@cardiff.ac.uk). 


\section{ABSTRACT}

During the last decade, numerous studies have associated genetic variations in complement components and regulators with a number of chronic and infectious diseases. The functional characterization of these complement protein variants, in addition to recent structural advances in understanding of the assembly, activation and regulation of the AP C3 convertase, have provided important insights into the pathogenic mechanisms involved in some of these complement related disorders. This knowledge has identified potential targets for complement inhibitory therapies which are demonstrating efficacy and generating considerable expectation in changing the natural history of these diseases. Comprehensive understanding of the genetic and non-genetic risk factors contributing to these disorders will also result in targeting of the right patient groups in a stratified medicine approach through better diagnostics and individually tailored treatments, thereby improving management of patients.

\section{Keywords:}

Complement, complotype, inflammation, alternative pathway, disease, mutation, polymorphism 


\section{The complement system}

Complement is a major component of innate immunity with crucial roles in microbial killing, apoptotic cell clearance, immune complex handling and modulation of adaptive immune responses (Ricklin, et al., 2010). Complement works as an amplification cascade, initiated through either the classical pathway (CP), the lectin pathway (LP) or the alternative pathway (AP). Activation of complement results in the formation of unstable protease complexes, named C3 convertases ( $\mathrm{C} 3 \mathrm{bBb}$ in the $\mathrm{AP} ; \mathrm{C} 4 \mathrm{~b} 2 \mathrm{a}$ in the $\mathrm{CP} / \mathrm{LP})$, which catalyze the central and most important step of complement activation: the cleavage of C3 to generate the activated fragment, $\mathrm{C} 3 \mathrm{~b}$. When nascent $\mathrm{C} 3 \mathrm{~b}$ is generated, a reactive thioester is exposed which is attacked by nucleophiles (such as amine groups) on adjacent surfaces, resulting in covalent binding of $\mathrm{C} 3 \mathrm{~b}$ to the target surface, marking it for destruction and initiating inflammation at the site of activation.

The AP is critical for efficient activation regardless of the trigger because it amplifies the response. In contrast to the CP and LP where activation is triggered by immune complexes and bacterial mannose groups respectively, the AP is intrinsically active. Spontaneous activation of C3 in plasma occurs through the "tick-over" mechanism, which is initiated by the generation of a fluid phase C3b-like molecule, called $\mathrm{C} 3 \mathrm{i}$ or $\mathrm{C} 3\left(\mathrm{H}_{2} \mathrm{O}\right)$, by aqueous hydrolysis of the internal C3 thioester (Pangburn, et al., 1981). Activation of C3 may also occur by continuous low rate cleavage of $\mathrm{C} 3$ to $\mathrm{C} 3 \mathrm{~b}$ by plasma proteases. The balance between the rate at which the initial trigger is amplified and the degree to which $\mathrm{C} 3 \mathrm{~b}$ and the AP C3-convertases are inactivated determines the progression of the complement cascade to cell damage and death. Foreign 
substances on microbial pathogens, antibodies, or mannan, tip the balance in favour of amplification, causing target opsonisation (Lachmann, 2009). The positive regulator, properdin, stabilizes the AP C3-convertase and serves as a focal point for promoting local amplification of complement (Kemper, et al., 2010). The terminal pathway fires when the AP C3-convertase incorporates one additional C3b molecule, which creates the C5-convertase and switches substrate specificity from C3 to C5, a C3 homologue that lacks the thioester. C5 cleavage triggers inflammation and leukocyte recruitment through production of C5a, and initiation of membrane attack complex (MAC) formation. The MAC contains C5b plus the complement components C6, C7, C8 and C9, and lyses cells by punching holes through the membrane (Muller-Eberhard, 1985).

Accelerated dissociation of the AP C3 convertase and inactivation of C3b are critical steps to maintain complement homeostasis and to prevent nonspecific damage to self-cellular components when complement is activated. These activities are performed primarily by factor $\mathrm{H}(\mathrm{fH})$, in collaboration with the plasma serine protease factor I (fl) (Rodriguez de Cordoba, et al., 2004). FH is an abundant plasma protein $(0.2-0.5 \mathrm{~g} / \mathrm{l})$ with an elongated structure presenting several binding sites for C3b and glycosaminoglycans (GAGs) along its length. The GAG-binding domains are key to protection of self-tissues as they locate $\mathrm{fH}$ to cell membranes where it dissociates deposited AP convertases and inactivates C3b. Self-tissues are also protected by membrane-bound proteins that restrict complement activation in three ways: i) acting as cofactor for proteolytic inactivation of $\mathrm{C} 3 \mathrm{~b}$ by fl; ii) accelerating convertase dissociation; iii) inhibiting MAC formation (Figure 1). Thus, in health, spontaneous activation of $\mathrm{C} 3$ in plasma is kept at a low level and further 
complement activation and C3b deposition is restricted to targets lacking surface regulators.

\section{Genotype-phenotype correlations between complement and disease}

The relationship between complement deficiencies and pathology has been recognized for over 50 years and complement is firmly implicated in a long list of diseases, responsible for sustaining a 'vicious cycle' of inflammation and perpetuating tissue damage. However, completion of the Human Genome Project during the last decade has catalysed expansion of this long list as studies have associated specific mutations and/or polymorphisms in complement components and regulators with predisposition to numerous rare and prevalent chronic inflammatory diseases, and with susceptibility to infection. Diseases associated with complement are genetically complex in that they are commonly associated with mutations and/or polymorphisms in more than one complement component. In addition, they are multifactorial in the sense that non-genetic risk factors and factors unrelated to complement also contribute to disease development and progression. Importantly, it is not unusual that the same gene or combination of genes is involved in several distinct pathological entities, perhaps because of the impact of non-complement drivers. Table 1 summarizes the complement genes associated with a number of different renal and ocular diseases to illustrate the complexities.

The functional characterization of disease-associated complement genetic variations has improved our understanding of these genetically complex diseases and, in some cases, unravelled the role that complement plays in pathogenesis. Complement dysregulation is a unifying pathogenic feature in 
many of these diseases. Remarkably, functional analyses have shown that there is a strong correlation between mutations causing particular functional alterations in a complement protein and specific susceptibility to a particular disease. A comprehensive understanding of the genetic component predisposing to the pathology and its functional consequences at the protein level is therefore critical to guide appropriate diagnostics and effective treatment in complement-related disorders.

1) Mutations in the $\mathrm{C}$-terminal region of $\mathrm{fH}$ are prototypical in aHUS.

Hemolytic uremic syndrome (HUS) is a rare, life threatening disease characterized by thrombocytopenia, Coombs test negative microangiopathic haemolytic anemia and acute renal failure. The commonest form of HUS follows a diarrhoeal prodrome and is associated with infections involving shiga-toxin producing E. coli strains (STEC-HUS; EHEC-HUS). However, five to ten percent of HUS patients lack an association with diarrhoea. This atypical form of HUS (aHUS), with an incidence of about $3 / 10^{6}$ per year and a prevalence of $1 / 10^{5}$ children in the whole European Union, has the poorest long-term prognosis. Recurrences in aHUS are common with a mortality rate that approaches 30\% (Noris and Remuzzi, 2005).

Although $\mathrm{fH}$ deficiencies were implicated in the pathogenesis of aHUS in the early 1980's, it was the pioneering work by Warwicker et al., published in 1998, which identified the association of the RCA gene cluster with aHUS (Warwicker, et al., 1998). These findings triggered a number of seminal studies that delineated the genetic predisposition to aHUS and provided fundamental insights into its pathogenic mechanisms, changing the earlier perception that 
aHUS was a pathology related to hypocomplementemia (lack of complement) to the realization that the disorder was caused by dysregulated complement activation (Caprioli, et al., 2001, Perez-Caballero, et al., 2001, Richards, et al., 2001).

aHUS is associated with mutations or polymorphisms in the genes encoding the complement regulatory proteins $\mathrm{fH}(\mathrm{CFH})$ (Caprioli, et al., 2001, Caprioli, et al., 2003, Perez-Caballero, et al., 2001, Richards, et al., 2001, Warwicker, et al., 1998) membrane cofactor protein (MCP) (Esparza-Gordillo, et al., 2005, Noris, et al., 2003, Richards, et al., 2003) and factor I (CFI) (Fremeaux-Bacchi, et al., 2004); (Kavanagh, et al., 2005), and with mutations in the genes encoding complement components factor $\mathrm{B}(C F B)$ (Goicoechea de Jorge, et al., 2007) and C3 (C3) (Fremeaux-Bacchi, et al., 2008). Mutations in thrombomodulin (THBD) have also been described in association with aHUS (Delvaeye et al, 2009). Missense mutations in CFH are prototypical of aHUS and the most prevalent genetic alteration, present in approximately $25 \%$ of the aHUS patients in all series. aHUS-associated CFH mutations cluster in the Cterminus of the protein, a region that is critical to the capacity of $\mathrm{fH}$ to bind cell surfaces and control local activation of complement (Figure 2). Carriers of these $\mathrm{CFH}$ mutations express $\mathrm{fH}$ molecules that possess normal regulatory activity in plasma but a limited capacity to bind and protect cells from complement lysis (Manuelian, et al., 2003, Perez-Caballero, et al., 2001, Sanchez-Corral, et al., 2004, Sanchez-Corral, et al., 2002). It is therefore the combination of an active complement system in plasma and a defective protection of cellular surfaces that determines the development of aHUS. These findings fit well with the identification of aHUS-associated loss-of-function mutations in MCP and $\mathrm{CFI}$; 
these mutations also lead to decreased protection of host cells from complement lysis without affecting significantly complement homeostasis in plasma (Figure 3) (Atkinson, et al., 2005).

The penetrance of disease in carriers of aHUS-associated mutations is approximately $50 \%$, indicating that additional genetic and environmental factors contribute to disease development. In fact, it is now well documented that concurrence of different genetic risk factors greatly influences predisposition to aHUS in carriers of mutations in $C F H, M C P, C F I$ and $C F B$ (Esparza-Gordillo, et al., 2005, Esparza-Gordillo, et al., 2006, Goicoechea de Jorge, et al., 2007, Martinez-Barricarte, et al., 2008, Neumann, et al., 2003). Among these additional risk factors are two relatively frequent $C F H$ and $M C P$ haplotypes that may determine decreased expression of $\mathrm{fH}$ and MCP respectively (Caprioli, et al., 2003, Esparza-Gordillo, et al., 2005, Liszewski, et al., 2007).

Factor B and C3 gain-of-function mutations are characteristic of a subgroup of aHUS patients showing persistent activation of the AP in plasma (Fremeaux-Bacchi, et al., 2008, Goicoechea de Jorge, et al., 2007, Roumenina, et al., 2012). From a pathogenic point of view it is intriguing that these $f B$ and C3 gain-of-function mutations, decreasing C3 plasma levels and causing different degrees of hypocomplementemia, are nevertheless associated with aHUS. One possible explanation is that increased complement activation caused by gain-of-function mutations, a situation that may be similar to that occurring during infection, coincides with an additional aHUS risk factor impairing surface protection. In support of this possibility, we note that carriers of $\mathrm{fB}$ or $\mathrm{C} 3$ gain-of-function mutations that develop aHUS are also carriers of the MCP risk haplotype (Goicoechea de Jorge, et al., 2007, Roumenina, et al., 
2012). In the case of mutations in C3 associated with aHUS, different experimental approaches have shown that these mutations alter the sensitivity of $\mathrm{C} 3 \mathrm{~b}$ to inactivation by $\mathrm{fH}$ and MCP and/or change the susceptibility of the AP C3 convertase to accelerated decay by $\mathrm{fH}$ and DAF ((Fremeaux-Bacchi, et al., 2008, Roumenina, et al., 2012); our unpublished results).

Taken together, genetic and functional analyses have established that aHUS involves complement AP dysregulation and develops as a consequence of defective protection of cellular surfaces from complement activation. Multiple hits, involving plasma and membrane-associated complement regulatory proteins as well as complement components, are likely required to cause dysregulation and significantly impair protection to host tissues. Environmental factors that activate complement likely modulate genetic predisposition and are also very important in aHUS. Infection, immunosuppressive drugs, cancer therapies, oral contraceptives, pregnancy and childbirth are important factors that trigger attacks of aHUS in some patients. In carriers of multiple strong aHUS genetic risk factors the contribution of the environment is probably minor.

On the other hand, in those with a low genetic predisposition, strong environmental factors may still precipitate disease. Whether this scenario explains the severe or fatal outcome of a small proportion of individuals with the more common diarrhoea-associated STEC-HUS remains to be determined (Fang et al., 2008).

\section{2) Complement fluid phase dysregulation and $D D D$}

Dense deposit disease (DDD) is a rare form of glomerulonephritis which affects both children and young adults and frequently results in end-stage renal 
disease (ESRD) (Smith, et al., 2011). The morphologic hallmark of DDD is the presence of electron-dense deposits within the glomerular basement membrane (GBM), as resolved by electron microscopy. The chemical composition of the dense deposits is largely unknown, although IgG is absent from them and other regions of the glomerulus, which excludes a role for immune complexes in dense deposit formation. DDD is associated with complement abnormalities which include persistent reduction of C3 serum levels and intense deposition of C3 fragments in GBM. The majority of DDD patients have C3 nephritic factors (C3NeF), autoantibodies against the AP convertase, in their plasma that may be causative. Familial cases of DDD are rare but extremely informative. The functional characterization of human DDD-associated $\mathrm{fH}$ and $\mathrm{C} 3$ mutations (Licht, et al., 2006, Martinez-Barricarte, et al., 2010) and previous studies in animal models (Hogasen, et al., 1995, Pickering, et al., 2002) have provided conclusive evidence that fluid phase complement dysregulation, resulting in the continuous activation of $\mathrm{C} 3$ in plasma, plays a major role in DDD pathogenesis (Figure 3).

Recently, the CFH genotype-phenotype correlation was formally established in a murine model. Factor $\mathrm{H}$-deficient mice $\left(\mathrm{Cfh}^{-1}\right)$ develop DDD as a consequence of massive activation of C3 (Pickering, et al., 2002). These mice present very low levels of $\mathrm{C} 3$ and complement activity in plasma. Introduction into $\mathrm{Cfh}^{-/}$mice of a transgenic $\mathrm{fH}$ molecule $\left(\mathrm{FH} \Delta_{16-20}\right)$ that mimics the $\mathrm{fH}$ mutations found in aHUS patients restored the C3 levels and the complement activity in the plasma of these $\mathrm{fH}$-deficient animals. As a result, $\mathrm{Cfh}{ }^{-/} \mathrm{FH} \Delta_{16-20}$ animals switch their disease phenotype from DDD to aHUS (Pickering, et al., 
2007), validating the conclusion that the combination of active complement in plasma with a decreased protection of cell surfaces leads to aHUS.

Further studies are still necessary to unravel the precise molecular events that lead to the development of DDD. An important step has been taken with the creation of $\mathrm{fH} / \mathrm{fl}$ double knockout mice; absence of $\mathrm{fl}$ protected the $\mathrm{fH}$ deficient mice from developing DDD, demonstrating that fluid phase activation of $\mathrm{C} 3$ and generation of iC3b is critical in pathogenesis in DDD (Rose, et al., 2008).

While mutations at the $\mathrm{C}$-terminus of $\mathrm{fH}$ are typical of aHUS and complete functional deficiency of $\mathrm{fH}$ is the prototypic mutation associated with DDD, there are both aHUS and DDD patients with partial $\mathrm{fH}$ deficiencies due to mutations in the CFH gene (Dragon-Durey, et al., 2004, Landau, et al., 2001, Levy, et al., 1986, Ohali, et al., 1998, Smith, et al., 2007). Overlap between syndromes illustrates their genetic complexity. Additional genetic and environmental factors likely provide the context that decides the pathological outcome in partial $\mathrm{fH}$ deficiencies. For example, concurrence of partial $\mathrm{fH}$ deficiencies with other mutations or polymorphisms that decrease protection to host cells will result in aHUS (Hakobyan, et al., 2010, Perez-Caballero, et al., 2001, Sanchez-Corral, et al., 2002), whereas the coincidence of partial fH deficiencies with strong complement activators like $\mathrm{C} 3 \mathrm{NeF}$ will trigger DDD (Licht, et al., 2006). DDD is part of a large and heterogeneous group of kidney pathologies, the C3 glomerulonephropathies (C3-GN), with distinct patterns of glomerular inflammation, mediated by complement dysregulation and characterized by glomerular deposition of C3 (Fakhouri, et al., 2010). C3Nef are also found in some non-DDD C3-GN patients, often with mutations in CFI and 
CFH (Servais et al., 2012), further illustrating the overlap between these complement dysregulation disorders and the requirement of particular combinations to trigger specific pathologies.

3) $A M D$ is an exemplar complex genetic disorder involving common complement polymorphisms.

Age-related macular degeneration (AMD), the commonest cause of blindness in the western world, shows a very high (40-70\%) and well characterized genetic component, including a large set of common polymorphisms in complement components and regulators (Gorin, 2012). Retinal drusen, the hallmark of AMD, was known to contain complement proteins based on immunohistochemical and biochemical analysis, a finding that initially had attracted little attention (Hageman and Mullins, 1999). A quantum shift in interest occurred in 2005 when several papers reported candidate region studies and whole-genome association analyses that implicated the region encoding $\mathrm{fH}$ at $1 \mathrm{q} 31$ as a major susceptibility locus for AMD (Edwards, et al., 2005, Hageman, et al., 2005, Haines, et al., 2005, Klein, et al., 2005). The $\mathrm{CFH}_{\mathrm{Y} 402 \mathrm{H}}$ allele (rs1061170) conferred a significantly increased risk of $A M D$ with an odds ratio (OR) between 2.1 and 7.4. The association of a $\mathrm{CFH}$ polymorphism with AMD strengthened the implication of complement in the pathogenesis of AMD and prompted subsequent candidate gene studies that identified additional associations (protective and nonprotective) of complement genes, including $\mathrm{CFI}, \mathrm{C} 3, \mathrm{C2} / \mathrm{CFB}, \mathrm{CFHR} 3 / \mathrm{CFHR} 1$ and C7, with AMD (Dinu, et al., 2007, Fagerness, et al., 2009, Gold, et al., 2006, 
Hughes, et al., 2006, Yates, et al., 2007). Together, these genetic data reinforce the concept that complement dysregulation is a major player in the pathogenesis of AMD.

The mechanism by which complement polymorphisms impact AMD risk is as yet unsolved, although it is clear that different polymorphisms can act additively to cause local complement dysregulation and pathology (Heurich, et al., 2011, Maller, et al., 2006). Some of them, like the $\mathrm{fH}_{621}(\mathrm{rs} 800292), \mathrm{fB}_{32 \mathrm{Q}}$ (rs641153) and C3 ${ }_{102 \mathrm{G}}$ (rs2230199) variants, alter AP convertase formation or regulation (Heurich, et al., 2011, Montes, et al., 2009, Tortajada, et al., 2009), while others like $\mathrm{fH}_{402 \mathrm{H}}$ ( $\mathrm{rs} 1061170$ ) may result in failure to recruit $\mathrm{fH}$ to sites where complement is activated by the accumulation of endogenous complement-activating compounds. For example, it has been recently reported that the $\mathrm{fH}_{402 \mathrm{H}}$ variant fails to bind malondialdehyde, a common lipid peroxidation product found in the aged retina and implicated in AMD (Weismann, et al., 2011).

The association of AMD with the $1 \mathrm{q} 31$ locus is complicated by the large number of polymorphisms within these regions and the strong linkage disequilibrium between them (Figure 4A). As a consequence, it is often difficult to ascribe risk to a specific protein or polymorphism in the inherited set - the haplotype. For example, the $\mathrm{FH}_{\mathrm{Y} 402 \mathrm{H}}$ polymorphism (rs1061170) is part of the common $\mathrm{H} 1$ haplotype of the $\mathrm{CFH}$ gene $(\mathrm{CFH})$ that encompasses several other linked polymorphisms in $\mathrm{fH}$ and $\mathrm{fH}$-related (FHR) proteins (Hageman, et al., 2006). These include a recently described common allelic variation in the CFHR1 gene; the *A variant of the FHR-1 protein, risk for AMD, differs from the *B variant by three amino acids (Abarrategui-Garrido, et al., 2009, Martinez- 
Barricarte, et al., 2012). A second $C F H$ haplotype, $H 2$, is protective for AMD and includes the $\mathrm{FH}_{\text {v62I }}$ (rs800292; odds ratio (OR) 0.54) polymorphism and a non-coding intronic SNP, while a second AMD-protective haplotype, $\mathrm{H} 4$, includes the deletion, common in Caucasians, of the CFHR1 and CFHR3 genes encoding the proteins FHR-1 and FHR-3 (Hageman, et al., 2005, Hughes, et al., 2006). In order to prove that a particular protein variant in the haplotype is responsible for altered disease risk it is necessary to demonstrate that the polymorphism has an effect on protein function or production that is compatible with the observed change in disease risk. Although this has now been achieved for some of the disease-associated complement polymorphisms, the task is far from complete; for example, the functional effect of the FHR-1 polymorphism described above and its contribution to AMD risk in the $\mathrm{H} 1$ haplotype is unknown. Recently, the prevalent aHUS-associated $\mathrm{FH}_{\mathrm{R} 1210 \mathrm{C}}$ mutation (Martinez-Barricarte et al., 2008) has been associated with early onset of AMD (Raychaudhuri et al., 2011), a remarkable finding illustrating that AMD has links not only with DDD, but also with other complement dysregulation disorders, including aHUS. As discussed above for partial $\mathrm{fH}$ deficiencies, additional genetic and environmental factors likely provide the context that decides the pathological outcome in carriers of the $\mathrm{FH}_{\mathrm{R} 1210 \mathrm{C}}$ mutation.

4) CFHR genes, FHR proteins and disease risk

The family of fH-related proteins (FHRs), revealed over the last two decades predominantly by the work of Zipfel and co-workers (Jozsi and Zipfel, 2008) are somewhat neglected, in large part because they are compared to $\mathrm{fH}$ 
itself (around $500 \mathrm{mg} / \mathrm{l}$ in plasma), relatively minor plasma components with concentrations in the range 5 to $50 \mathrm{mg} / \mathrm{l}$. The genes CFHR3, CFHR1, CFHR4, CFHR2 and CFHR5 encoding these FHR proteins are located downstream and closely linked to the $\mathrm{CFH}$ gene (Figure 4A). Genomic and sequence analyses of the CFH-CFHR1-5 gene region suggest that the CFHR genes originated from the CFH gene by tandem duplication events (Perez-Caballero, et al., 2001). All the CFHR genes retained, with different degrees of sequence conservation, the exons that encode the $\mathrm{C}$-terminal region of $\mathrm{fH}$ (Figure 4B), explaining the capacity of most FHR proteins to interact with C3b, iC3b, C3dg and carbohydrates (Jozsi and Zipfel, 2008, Skerka and Zipfel, 2008, Zipfel, et al., 1999). None of the FHR proteins contain regions homologous with the complement regulatory SCRs 1-4 of fH; however, weak cofactor and/or decay accelerating activities have been reported for some of them. Although the physiological relevance of these interactions and activities is not yet fully clear, it is generally accepted that the FHRs influence complement activation and regulation via their interaction with $\mathrm{C} 3 \mathrm{~b}$ and $\mathrm{C} 3 \mathrm{dg}$ fragments and carbohydrates on particular surfaces. How FHRs exert this influence is still controversial.

It has been suggested that some FHR proteins (like FHR3 and FHR1) modulate complement regulation, competing with $\mathrm{fH}$ for binding to $\mathrm{C} 3 \mathrm{~b}$ and interfering with $\mathrm{fH}$ complement regulatory activities (Fritsche, et al., 2010, Heinen, et al., 2009). An argument against this is the relatively low plasma concentrations of the FHR proteins compared to $\mathrm{fH}$ noted above. However, a differential binding specificity of the $\mathrm{FHRs}$ and $\mathrm{fH}$ proteins for $\mathrm{C} 3 \mathrm{~b}$ in the context of particular carbohydrates may increase the affinity of these FHR molecules locally to allow them to compete efficiently with $\mathrm{fH}$. The hybrid $\mathrm{CFH}:: \mathrm{CFHR} 1$ 
genes found associated with aHUS may support this possibility ((Venables, et al., 2006); see below). An interesting, and contrasting alternative to the competition theory is the suggestion that FHR4A, FHR4B and FHR3 regulate complement activation by enhancing the cofactor activity of $\mathrm{fH}$ (Hebecker and Jozsi, 2012, Hellwage, et al., 1999).

Experimental evidence has accumulates in recent years supporting the contention that some FHRs have endogenous complement regulatory functions. FHR1 is reported to act downstream of $\mathrm{fH}$ and inhibit the C5-convertase, while FHR3 has cofactor activity for factor I-mediated inactivation of C3b (Fritsche, et al., 2010, Heinen, et al., 2009). Cofactor activity has also been reported for the FHR4B isoform (Hellwage, et al., 1999) and for FHR5 (McRae, et al., 2005); however, these activities are weak and their physiological relevance has been questioned (Hebecker and Jozsi, 2012). Finally, it was recently suggested that the FHRs may promote complement activation; the A isoform of FHR4 enhanced complement activation via its interaction with $\mathrm{C} 3 \mathrm{~b}$ (Hebecker and Jozsi, 2012).

The $\mathrm{CFH}-\mathrm{CFHR} 1-5$ gene region shows significant genetic variability. In addition to conventional polymorphism due to sequence variations, the presence within the region of large genomic duplications (ranging in size from 1.2 to $38 \mathrm{~kb}$ ) makes the region highly prone to genomic rearrangements through gene conversion and non-homologous recombination (Figure 4A) (PerezCaballero, et al., 2001). These rearrangements are readily identified by MLPA (Multiplex Ligation-dependent Probe Amplification) technologies (Venables, et al., 2006), CNV microarrays or western blots (Abarrategui-Garrido, et al., 2009, Zipfel, et al., 2007). Notably, several rearrangements have been identified in 
recent years associated with different pathologies involving complement dysregulation. They are remarkable "experiments of nature" that may help to clarify some of the current uncertainties regarding the function of the FHR proteins (Table 2).

A very prevalent rearrangement in this region, a true common polymorphism in humans, is the deletion of the CFHR1 and CFHR3 genes, likely resulting from a single non-homologous recombination event between a duplicated region downstream of the $C F H$ and $C F H R 1$ genes, which became fixed early in human evolution, likely implying a selective advantage (Hageman, et al., 2006). The deletion of the CFHR1 and CFHR3 genes is included in a single extended $\mathrm{CFH}$-CFHRs haplotype, $\mathrm{H} 4$, that associates with lower risk of AMD (Hughes, et al., 2006) and IgA nephropathy (Gharavi, et al., 2011) and increased risk of SLE (Zhao, et al., 2011). This remarkable finding suggests that binding of these FHR proteins, and capacity to regulate complement, directly or by complementing or competing with $\mathrm{fH}$, can be beneficial or detrimental depending on the circumstances.

The deletion of the CFHR1 and CFHR3 genes is likely also protective in aHUS (Abarrategui-Garrido, et al., 2009, Martinez-Barricarte, et al., 2012); however, the frequency of homozygosity for the CFHR3-CFHR1 deletion is increased in aHUS as a consequence of the association between complete deficiency of the FHR1 protein and the generation of anti-fH autoantibodies (Abarrategui-Garrido, et al., 2009, Dragon-Durey, et al., 2009, Jozsi, et al., 2008, Moore, et al., 2010, Zipfel, et al., 2007). This is an intriguing association for which there is no clear explanation. Importantly, the anti-fH autoantibodies recognize the $\mathrm{C}$-terminus of $\mathrm{fH}$, the region critical for the development of aHUS 
that is nearly identical in FHR1; not surprisingly, the autoantibodies cross-react with FHR1. It has been suggested that deficiency of FHR1 may result in a failure of central and/or peripheral tolerance to the homologous region in $\mathrm{fH}$, but there are other possibilities, including cross-reactivity with microbial antigens.

Another relatively frequent rearrangement in the $\mathrm{CFH}-\mathrm{CFHR}$ region involves an unequal crossover between homologous regions in the 3' ends of CFHR3 and CFHR4 genes that specifically removes the CFHR1 and CFHR4 genes. This deletion is also found in aHUS patients in association with anti-fH autoantibodies for the reasons indicated above (Abarrategui-Garrido, et al., 2009), and is also associated with C3-glomerulopathies (C3-GN).

Most interesting are the various genomic rearrangements between the 3 end exons of $\mathrm{CFH}$ and the homologous regions in CFHR1 or CFHR3, which have been associated with aHUS (Francis, et al., 2012, Venables, et al., 2006). All result in the generation of $C F H:: C F H R 1$ or CFH::CFHR3 hybrid genes that alter the $\mathrm{C}$-terminal region of $\mathrm{fH}$, further illustrating the remarkable correlation between $\mathrm{C}$-terminal region deficits in $\mathrm{fH}$ and aHUS. On the other hand, the CFH::CFHR1 hybrid gene in which the $\mathrm{C}$-terminal exons of $\mathrm{fH}$ have been replaced by those in FHR1 demonstrates that, despite their sequence similarities, the $\mathrm{C}$-terminal regions of $\mathrm{fH}$ and $\mathrm{FHR} 1$ have distinct binding specificities and do not compete - at least not for substrates that are relevant in aHUS.

A unique set of genomic rearrangements in the CFHRs gene region are found associated with C3-GN. The most remarkable of these involves the duplication of the first two SCRs of the FHR5 protein; this by itself defines a monogenic disorder endemic in Cyprus denominated FHR5 nephropathy 
(Athanasiou, et al., 2011, Gale, et al., 2010, Gale and Pickering, 2011). Other rearrangements associated with C3-GN include a hybrid CFHR3::CFHR1 gene (Malik, et al., 2012) and an internal duplication of the FHR1 protein (Abarrategui-Garrido, et al., 2010). The functional implications of these rearrangements are currently being investigated; it is unclear whether they represent loss of function or gain of function mutations.

Apart from these genomic mutations and polymorphisms, other diseaseassociated polymorphisms in FHR proteins include the $\mathrm{FHR}-1^{*} \mathrm{~A} /{ }^{*} \mathrm{~B}$ variant described above; possession of the ${ }^{*} \mathrm{~B}$ variant is risk for aHUS, while possession of the *A variant is risk for AMD (Abarrategui-Garrido, et al., 2009, Martinez-Barricarte, et al., 2012), further emphasizing the dichotomy of complement regulation in these disorders. The ${ }^{*} \mathrm{~A}$ and ${ }^{*} \mathrm{~B}$ variants differ by three amino acids with * $\mathrm{B}$ having higher homology with $\mathrm{fH}$ (Figure 4B); how these differences affect function remains unclear. Five different polymorphisms in the CFHR5 gene have been described and associated with risk of aHUS, DDD and AMD (Abrera-Abeleda, et al., 2011, Monteferrante, et al., 2007, Narendra, et al., 2009).

The CFH-CFHRs genetic hotspot is an area in which we anticipate much more activity in the near future. It seems inevitable that other disease associated polymorphisms in this complex gene family will emerge and their functional characterization will resolve the mechanisms by which in health $\mathrm{fH}$ and the FHR proteins collaborate to control complement on different surfaces.

\section{The complotype}

1) A predictor of disease risk. 
The complotype describes the repertoire of inherited common polymorphisms in genes encoding complement proteins and regulators. This term was used originally to describe haplotypic combinations of genetic variants of MHC-linked complement genes (Alper, et al., 1986), but has been expanded recently to include variants in the whole complement system (Harris, et al., 2012). Functional analyses of polymorphic variants within the AP demonstrate that they work together to dictate the balance between activation and regulation, and thereby set the complement activating capacity of an individual (Heurich, et al., 2011, Montes, et al., 2009, Tortajada, et al., 2009). Inheritance of more active variants of $\mathrm{AP}$ components $(\mathrm{C} 3, \mathrm{fB})$ or less active variants of regulators ( $\mathrm{fH}, \mathrm{fl}, \mathrm{MCP}$ ) swings the balance in favour of AP activation and inflammation, while inheritance of less active variants of components and more active regulators dictates less AP activation and inflammation. The functional effect of each AP polymorphic variant is small, as might be expected from a common polymorphism. However, their combined effects can be striking, particularly when they directly influence the AP amplification loop, the means by which small activation triggers are massively amplified. Common non-coding polymorphic variation also influences expression levels of complement proteins, adding an extra dimension to the concept of the complotype.

The inherited pattern of complement variants, and the expression levels of these proteins, have direct effects on systemic activity and thus alter risk for pathologies driven by complement activation. However, the contribution of the complotype to disease risk is complex - in addition to overall complement activity, the pattern of inherited variants influences development of pathology in different ways depending on the underlying disease mechanism (Table 1). 
Genetic studies in AMD, DDD and aHUS described above, show that often multiple hits are needed to cause disease. For example, in aHUS, disease requires not only the disease-associated mutation in an AP protein, but also altered expression of another AP protein or a risk complotype (Esparza-Gordillo, et al., 2005, Hakobyan, et al., 2010). Protein variants which are risk for aHUS, a disease caused by complement dysregulation at the cell surface, may not be risk for other pathologies caused primarily by dysregulation in the fluid phase.

2) Molecular complotyping in complement dysregulation disorders.

Molecular analyses provide most of the information required to define an individual's complotype, although some aspects, for example plasma concentrations of components, can be ascertained only by protein assays. Complement molecular diagnostics contribute to identification and understanding of complement dysregulation disorders by providing basic information on complement mutations and polymorphisms, and by building from these datasets algorithms that are predictive of disease susceptibility, progress or response to therapy.

In the simplest situation, a single complement gene or set of genes is demonstrated to be associated with development of a particular pathology; identification of the responsible complement protein mutations/polymorphisms and their effects on protein function then provides direct help in tailoring management and therapeutic strategies. Even this superficially simple task is often one of significant complexity. In the case of aHUS, for example, complotyping will include a search for mutations not just in the $\mathrm{CFH}$ gene, but also in $M C P, C F I, C F B$ and $C 3$ genes, by PCR exon amplification and DNA 
sequencing, together with copy number variation (CNV) analysis of the CFHCFHRs gene region to identify genomic rearrangements, deletions and duplications. Thereafter, interpretation of the findings is not always straightforward, frequently requiring mutation segregation analysis between affected and unaffected family members, searches in the general population to identify and eliminate rare polymorphisms, and an analysis of the impact of the mutation on either protein expression or function (Tortajada, et al., 2012). Current technologies are limiting because of cost and time constraints in analysis of these numerous genes and interpretation of the variability of the complement components; however, recent advances in DNA sequencing technologies are generating enormous expectations in the community. Nextgeneration sequencing and the continuously falling cost and increasing speed of sequencing will solve some of these problems by making it possible to undertake a complete characterization of genetic variability in all complement components in an individual at reasonable cost. These data will only be of value if linked to advanced informatics to identify relevant patterns and rationalize mutation analysis of the whole set of complement genes. There will be a need to develop predictive algorithms, likely different for each disease, to estimate risk based on complotype, other genetic factors and environmental or other exogenous factors. An excellent example of this is the case of AMD where genetic variations in complement proteins are additive in their effects on disease susceptibility and interact strongly with other genetic and non-genetic factors (for example, smoking) (Hecker, et al., 2010, Heurich, et al., 2011, Martinez-Barricarte, et al., 2012, Reynolds, et al., 2009, Scholl, et al., 2008). 
In the future, we predict that analysis of an individual's complotype will be widely used, in conjunction with environmental and other known risk factors, to predict disease risk and course. Complement quantitative traits must also be incorporated into the disease-predictive algorithms as complement protein levels show important inter-individual variability and are relatively stable characteristics with a high heritability (Buil, et al., 2010, Esparza-Gordillo, et al., 2004, Sanchez-Corral, et al., 1995).

A particular challenge is the identification of biomarkers that may help to anticipate development of the disease in predisposed individuals and be useful in monitoring disease activity and response to treatment in patients.

Measurement of complement activation products is likely to be an important add-on to the genetically determined complotype in such analyses; even in isolation, measures of complement activation have been shown to be predictive of disease course in diseases as diverse as AMD and multiple sclerosis (MS) (Ingram, et al., 2012, Reynolds, et al., 2009, Scholl, et al., 2008, Smailhodzic, et al., 2012). Assay automation, multiplexing and other recent advances in -omics technologies has opened a window of opportunity for rapid and substantial progress in this area.

3) The role of the complotype in patient stratification and choice of therapy.

We are now in the age of stratified medicine, the stated goal of which is to deliver the right drug or other intervention to the right patient at the right time. The concept is built on understanding that the genetic makeup of an individual impacts their risk of developing a particular disease, their disease course and their response to therapies. Stratifying patients into groups based on likely 
outcome and responsiveness to treatment will deliver better outcomes at lower cost because those most likely to respond are identified early and treated appropriately. For complement-mediated diseases, defining the complotype will be a key component of patient stratification and personalization of therapy. To take AMD as an example, individuals presenting with early disease would be complotyped using appropriate genetic (outlined above) and/or protein analyses, including measures of plasma levels of key components and activation products. Those with "high risk" complotypes, defined as carriers of multiple risk alleles (CFH-402H, CFH-62V, CFHR1*A, CFB-32R, C3-102G, others), particularly accompanied by evidence of complement activation, would be stratified for therapies targeting complement activation. Those with a low risk complotype and no evidence of ongoing complement activation would be stratified to other therapeutic options.

Defining the complotype will also help evolve new therapeutic strategies in complex diseases where complement may play a role in a subset of patients. For example, MS is a highly complex disease that is currently impossible to treat (Compston and Coles, 2002). The disease is heterogeneous, likely representing a number of overlapping clinical entities, and the numerous failures of initially promising agents in clinical trials likely reflects this fact some respond but most don't. Better stratification of MS patients into disease subgroups is essential for future drug development, not least because it will enable selection of appropriate patients into trials, and is attracting much effort. A role for complement in MS has been suggested for more than thirty years based on studies in animal models (Ingram, et al., 2009, Linington, et al., 1989, Morariu and Dalmasso, 1978); however, data from patients has been 
inconsistent, likely reflecting disease heterogeneity (Lassmann, 2004). Based upon pathological and clinical evidence, Lassmann described four subgroups in MS that differed in the underlying pathology; one of these, Type II - some 30\% of patients, involved abundant complement activation, but the other subgroups did not (Lucchinetti, et al., 2000). Because this stratification required access to brain tissue - biopsy or autopsy - it has been of little value clinically. However, several recent reports describing measurement of complement proteins and activation products, in CSF or plasma, as biomarkers of disease opens up the real prospect of identifying those patients most likely to benefit for inclusion in trials of anti-complement drugs (Ingram, et al., 2012, Ingram, et al., 2010, Ingram, et al., 2010). Although some individual complement polymorphisms have been explored as potential susceptibility factors, there has been no broad brush analysis of complement genetic associations with MS; a combination of proteomic and genomic complotype analyses might provide a tractable way of identifying the complement-driven subset, enabling targeted trials of anticomplement therapies. Similar issues pertain in many other chronic inflammatory diseases. In AD, complement has been implicated both as a protective and destructive player (Bonifati and Kishore, 2007, Veerhuis, et al., 2011). Evidence for complement activation is found in tissues, CSF and plasma but no clear picture of how complement influences the disease has emerged. Complotyping, particularly in early disease or in those at high risk of developing disease (mild cognitive decline for example), may be helpful in identifying subgroups or stages of the disease that might benefit from anti-complement therapy, 
4) The complotype defines disease-driving complement pathways.

Analysis of the complotype will, by identifying which complement pathway is most important in driving dysregulation and pathology in a particular disease, aid choice of therapy. Diseases of AP dysregulation, linked to mutations in AP components or regulators, are most likely to be ameliorated by drugs that target the AP, while diseases in which the $\mathrm{CP}$ is the driver will be best treated using $\mathrm{CP}$ inhibitory drugs. Hereditary angioedema (HAE) provides the perfect example of the latter scenario. Mutations in the C1inh gene result in deficiency of $\mathrm{C} 1 \mathrm{inh}$ and dysregulation of the $\mathrm{CP}$; replacement therapy using purified $\mathrm{C} 1 \mathrm{inh}$ restores homeostasis (Cicardi and Zanichelli, 2010). Surprisingly, despite its long and successful record of use in HAE, C1inh therapy has not been used for other disease of complement dysregulation - this may in part be because it has not been clear which diseases are CP-driven. In contrast, a much more recently developed complement therapeutic is finding broader use. Eculizumab ${ }^{\mathrm{TM}}$, a blocking monoclonal antibody against human C5 that inhibits C5a and MAC generation (Rother, et al., 2007), was first successfully used for treatment of paroxysmal nocturnal hemoglobinuria (Brodsky, 2009), a hemolytic and thrombotic disorder caused by deficiency of GPI-linked proteins (including complement regulators CD55 and CD59) on blood cells (Takeda, et al., 1993). Erythrocytes, deficient in surface regulators, activate complement, probably via the AP, and are lysed by MAC formation; blocking C5 prevents MAC formation and rescues patients from dependence on transfusions. Eculizumab was first suggested as a therapy for DDD in 2007 (Smith, et al., 2007), and soon after tested with good effect in aHUS patients to prevent relapses of the disease and recurrences after transplantation (Mache, et al., 2009, Nurnberger, et al., 2009). 
Based on the excellent results obtained in phase II clinical trials during 2009-10, Eculizumab was approved by the US Food and Drugs Administration and the European Medicines Agency and has rapidly become the accepted therapy in patients with aHUS, both as a rescue therapy in acute episodes and as prophylaxis in labile patients and following renal transplant.

Isolated case reports describe a heterogeneous response in cases of C3$\mathrm{GN}$, including DDD, indicating that further research is needed to define the subgroup of C3-GN patients in whom Eculizumab therapy may be effective (Bomback, et al., 2012, Daina, et al., 2012, Vivarelli, et al., 2012). A Phase II study of systemic Eculizumab therapy in dry AMD is scheduled to report July 2012.

It is at first sight surprising that a therapy targeting the terminal pathway would be effective in diseases of AP dysregulation. C3 convertase assembly and C3 fragment deposition will continue unhampered, provoking the conclusion that $\mathrm{C} 5 \mathrm{a}$ and MAC are major drivers of pathology in these diseases. It is not yet clear whether deposition of $\mathrm{C} 3$ fragments and other early activation products causes residual injury in Eculizumab-treated aHUS and DDD patients; however, in PNH patients treated with Eculizumab, C3 fragment opsonised erythrocytes are removed in spleen and liver, reducing circulating half-life (Risitano, et al., 2009). There would thus be some advantage in using therapies that target the AP convertase and switch off activation. A recombinant human $\mathrm{CR} 2 /$ factor $\mathrm{H}$ fusion protein, TT30, has been developed that fits the bill and is in Phase I trials in PNH (Fridkis-Hareli, et al., 2011); its use in other AP dysregulation diseases, either alone or in combination with Eculizumab, is anticipated. 
5) The complotype also impacts on infectious diseases.

So far we have focused on the relevance of the complotype to acute or chronic inflammatory diseases; however, the principle role of complement is to kill invading bacteria so a role in infection is obvious. While a complotype that provides a more active complement system will increase risk in inflammatory diseases, the opposite is true in infection where a more active complement system will more efficiently target pathogens and is thus protective. Evidence in support of this is provided from comparison of complement polymorphisms in different populations; in communities at high risk of death from infection, for example, in Sub-Saharan Africans, there is a much higher frequency of polymorphisms that increase complement activity, a more active complotype, compared to low infection risk communities (Fridkis-Hareli, et al., 2011). A direct effect of the complotype on infection risk was revealed by a recent meningococcal disease GWAS (Davila, et al., 2010). A SNP in CFH (rs1065489; E936D) was identified where the $D$ allele was protective for survival after infection. The functional effect of this SNP is not yet clear, in part, because it is in strong LD with other SNPs along the CFH-CFHR3-CFHR1 region within CFH haplotype $\mathrm{H} 3$ (see above). Nevertheless, it is clear that polymorphisms in $\mathrm{fH}$ or FHRs influence risk of meningococcal disease by altering complement activation either in plasma or on the bacterial surface, possibly by altering function or relative expression levels of these key components. Although GWAS is a powerful way of identifying disease associations when allele frequency is high, linkage to less common polymorphisms can be missed and are only found when sought in a targeted manner. For example, a regulator element 
polymorphism in $\mathrm{CFH}$, found by a targeted approach to be associated with meningococcal disease, caused altered plasma fH levels (Haralambous, et al., 2006), while a polymorphism in complement C5 (rs17611;V802I), of unknown functional effect, was linked to poor outcome in bacterial meningitis (Woehrl, et al., 2011).

\section{Restoring homeostasis in diseases of complement dysregulation.}

Inter-individual differences in overall complement activity caused by the polymorphisms comprising the complotype are subtle, and even the diseaselinked complement protein mutations often cause relatively small changes in activity. Impact of these small changes builds over time and hence many of the associated pathologies are chronic, evolving over years. Using drugs that completely block complement activation or effectors in these circumstances seems excessive. Except in acute episodes, complete inhibition of complement is not only unnecessary but is also potentially harmful, increasing risk of infection and other pathologies (Asghar and Pasch, 2000). The identification and characterization of protective disease-associated complement polymorphisms (Heurich, et al., 2011, Montes, et al., 2009, Tortajada, et al., 2009) suggests that down-modulation without causing complete inhibition would be a measured and effective approach to an "over-active" complotype. In the case of $\mathrm{HAE}$, drugs that cause relatively modest increases in plasma levels of C1inh, either by enhancing synthesis (anabolic steroids) or reducing consumption (protease inhibitors) are remarkably effective at preventing attacks (Cicardi and Zanichelli, 2010). Perhaps similar strategies to modestly increase plasma fH concentrations by enhancing production, supplementing with 
exogenous protein or re-balancing the complex interplays with fHR proteins, will be effective, low-risk and affordable as prophylactic therapy for diseases like aHUS, DDD and AMD. Knowledge of the complotype will guide such "fine tuning" approaches to the treatment of complement dysregulation.

\section{Conclusions.}

The complotype is a concept that will radically alter the way we consider the complement system and the way that complement contributes to disease. It starts from the knowledge that individuals inherit very different complement systems that impact on their susceptibility to infections and risk of developing particular diseases. Advances in genomics and proteomics make it possible to assess an individual's complotype and use this information for prediction of disease risk or outcome, counselling on behaviour modification and making decisions on therapies. This patient-directed approach will enable better targeting of available drugs and guide future development of drugs tailor-made to redress the balance when complement is dysregulated. 


\section{Acknowledgements.}

The work of the authors described in this review was supported by the Wellcome Trust (068823; to CLH) and the MRC (G0701298; to CLH and BPM). SRdeC is supported by the Spanish Ministerio de Economia y Competitiviad (SAF2010-26583), the Communidad de Madrid (S2010/BMD-2316) and the Fundación Renal Iñigo Alvarez de Toledo.

\section{Disclosures.}

SRdeC has undertaken consultancy work for Alexion and is listed as a co-inventor on a patent held by Secugen SL, the Agencia Estatal Consejo Superior de Investigaciones Cientificas and the University of Navarra, regarding a method for the prediction of risk of developing AMD in the Spanish population. BPM has undertaken consultancy work for Baxter, Viropharma and Alexion. BPM and CLH are named on a patent held by Cardiff University that protects monoclonal antibodies specific for the $\mathrm{Y} 402 \mathrm{H}$ variants of factor $\mathrm{H}$. None of these interactions has influenced the results and interpretations in this manuscript. 


\section{Figure Legends.}

\section{Figure 1. Activation and regulation of the complement system.}

Cleavage of $\mathrm{C} 3$ to generate $\mathrm{C} 3 \mathrm{~b}$ is the critical event in complement activation. The classical (CP) and lectin (LP) pathways involve recognition of target-bound antibody through $\mathrm{C} 1 \mathrm{q}$ binding $(\mathrm{CP})$, or pathogen-specific carbohydrates by MBL (LP). The associated protease units ( $\mathrm{C} 1 \mathrm{~s}$ and MASP-2 respectively) then cleave $\mathrm{C} 4$ and $\mathrm{C} 2$, leading to formation of the $\mathrm{C} 3$ convertase $\mathrm{C} 4 \mathrm{~b} 2 \mathrm{a}$. In the alternative pathway (AP), continuous, low level, activation of C3 by spontaneous hydrolysis of the internal C3 thioester or cleavage by plasma proteases generates C3 $\left(\mathrm{H}_{2} \mathrm{O}\right)$, a C3b-like molecule, or C3b, which can bind fB to form an AP convertase which cleaves $\mathrm{C} 3$ to C3b. In the AP amplification loop (circle arrows), C3b, either membrane-bound or in the plasma, binds factor $\mathrm{B}(\mathrm{fB})$ generating additional AP C3 convertases that cleave many C3 molecules into C3b amplifying complement activation. The AP C3/C5-convertases are very labile enzymatic complexes (half-life of about $1 \mathrm{~min}$ ). However, binding of properdin $(P)$ stabilises the enzyme, extending its half-life more than 10 -fold. Activation of C3 by a membrane bound C3 convertase causes cluster deposition of $\mathrm{C} 3 \mathrm{~b}$ in the vicinity of the convertase. Incorporation of an additional $\mathrm{C} 3 \mathrm{~b}$ molecule to the $\mathrm{C} 3$ convertase creates a new enzyme, the C5 convertase, $\mathrm{C} 3 \mathrm{bBbC} 3 \mathrm{~b}$ or $\mathrm{C} 4 \mathrm{~b} 2 \mathrm{a} 3 \mathrm{~b}$, which cleaves $\mathrm{C} 5$ to $\mathrm{C} 5 \mathrm{~b}$ and $\mathrm{C} 5 \mathrm{a}$. C5a is a highly proinflammatory polypeptide, whereas $\mathrm{C} 5 \mathrm{~b}$ initiates the formation of the lytic pore, the membrane attack complex (MAC) (terminal pathway). Complement homeostasis and protection of self-tissues from accidental complement attack is provided by proteins present in plasma and on cell membranes (boxes) which 
either catalyze proteolytic inactivation of $\mathrm{C} 3 \mathrm{~b} / \mathrm{C} 4 \mathrm{~b}$ by $\mathrm{fl}(\mathrm{MCP}, \mathrm{CR} 1, \mathrm{fH}, \mathrm{C} 4 \mathrm{bp}$ ) or accelerate convertase dissociation (DAF, CR1, fH, C4bp).

Figure 2. Mutations in $\mathrm{fH}$ found in aHUS and DDD patients.

The location of most of the $\mathrm{fH}$ mutations thus far characterized in aHUS and DDD patients is indicated in a diagram of the structure of human $\mathrm{fH}$ showing the 20 SCR repeats. The mutations associated with DDD are highlighted with a black box. Note that mutations associated with aHUS are clustered in the Cterminus, the region of factor $\mathrm{H}$ that is critical for the control of $\mathrm{C} 3 \mathrm{~b}$ deposited on cell surfaces.

Figure 3. Complement activation in different glomerulopathies.

Schematic representation of the consequences of complement dysregulation in aHUS, where surface dysregulation results in strong C5 activation, and in DDD, where fluid phase activation primarily results in massive generation of $\mathrm{C} 3 \mathrm{~b}$ and iC3b. In other C3-GN, the situation may vary depending on the proteins involved.

Figure 4. CFHRs gene organization and structure of the FHRs proteins.

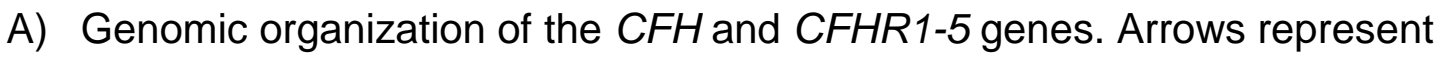
the genes with their names. Blue lines above the genes indicate the extent of linkage disequilibrium within three different SNP LD blocks. The coloured boxes underneath indicate the sequence repeats within this genomic region, labelled with the same letter (i.e., A, A', A"). The vertical lines indicate the positions of the exons of the $\mathrm{CFH}$ and $\mathrm{CFHRs}$ genes. 
B) Structural organization of the $\mathrm{fH}$ and FHR proteins, including the $F H R 1^{*} A$ and $F H R 1^{*} B$ allotypes and the FHR4A and FHR4B isoforms. Short consensus repeats (SCRs) are represented by ovals and are numbered from the $\mathrm{N}$-terminal end. Homologous SCRs are aligned and the amino acid differences from $\mathrm{fH}$ are indicated for SCR-3, -4 , and -5 of FHR1 ${ }^{\star} \mathrm{A}$ and FHR1 ${ }^{*} \mathrm{~B}$. Homologous SCRs are depicted with the same colour where they have greater than $80 \%$ amino acid identity. The colour code use in A to identify the different genomic sequence repeats has been maintained to correlate the SCR similarities with the genomic duplications. 


\section{References}

Abarrategui-Garrido, C., Martínez-Barricarte, R., López-Lera, A., FarizaRequejo, E., Ruivo, C., Bedoya-Pérez, R., Córdoba, S.R.d., López-Trascasa, M., Sánchez-Corral, P. 2010. Proteomics-based discovery of an abnormal, internally duplicated CFHR1 protein which associates with renal pathology in a Spanish family. Molecular Immunology 47, 2200.

Abarrategui-Garrido, C., Martinez-Barricarte, R., Lopez-Trascasa, M., de Cordoba, S.R., Sanchez-Corral, P. 2009. Characterization of complement factor $\mathrm{H}$-related (CFHR) proteins in plasma reveals novel genetic variations of CFHR1 associated with atypical hemolytic uremic syndrome. Blood 114, 4261.

Abrera-Abeleda, M.A., Nishimura, C., Frees, K., Jones, M., Maga, T., Katz, L.M., Zhang, Y., Smith, R.J. 2011. Allelic variants of complement genes associated with dense deposit disease. J Am Soc Nephrol 22, 1551.

Alper, C.A., Awdeh, Z., Raum, D., Yunis, E.J. 1986. Complement genes of the major histocompatibility complex (complotypes), extended haplotypes and disease markers. Biochem Soc Symp 51, 19.

Asghar, S.S., Pasch, M.C. 2000. Therapeutic inhibition of the complement system. Y2K update. Front Biosci 5, E63.

Athanasiou, Y., Voskarides, K., Gale, D.P., Damianou, L., Patsias, C., Zavros, M., Maxwell, P.H., Cook, H.T., Demosthenous, P., Hadjisavvas, A., Kyriacou, K., Zouvani, I., Pierides, A., Deltas, C. 2011. Familial C3 glomerulopathy associated with CFHR5 mutations: clinical characteristics of 91 patients in 16 pedigrees. Clin J Am Soc Nephrol 6, 1436.

Atkinson, J.P., Liszewski, M.K., Richards, A., Kavanagh, D., Moulton, E.A. 2005. Hemolytic uremic syndrome: an example of insufficient complement regulation on self-tissue. Ann N Y Acad Sci 1056, 144.

Bomback, A.S., Smith, R.J., Barile, G.R., Zhang, Y., Heher, E.C., Herlitz, L., Stokes, M.B., Markowitz, G.S., D'Agati, V.D., Canetta, P.A., Radhakrishnan, J., Appel, G.B. 2012. Eculizumab for Dense Deposit Disease and C3 Glomerulonephritis. Clin J Am Soc Nephrol 7, 748. 
Bonifati, D.M., Kishore, U. 2007. Role of complement in neurodegeneration and neuroinflammation. Mol Immunol 44, 999.

Brodsky, R.A. 2009. How I treat paroxysmal nocturnal hemoglobinuria. Blood 113,6522 .

Buil, A., Tregouet, D.A., Souto, J.C., Saut, N., Germain, M., Rotival, M., Tiret, L., Cambien, F., Lathrop, M., Zeller, T., Alessi, M.C., Rodriguez de Cordoba, S., Munzel, T., Wild, P., Fontcuberta, J., Gagnon, F., Emmerich, J., Almasy, L., Blankenberg, S., Soria, J.M., Morange, P.E. 2010. C4BPB/C4BPA is a new susceptibility locus for venous thrombosis with unknown protein $S$ independent mechanism: results from genome-wide association and gene expression analyses followed by case-control studies. Blood 115, 4644.

Caprioli, J., Bettinaglio, P., Zipfel, P.F., Amadei, B., Daina, E., Gamba, S., Skerka, C., Marziliano, N., Remuzzi, G., Noris, M. 2001. The molecular basis of familial hemolytic uremic syndrome: mutation analysis of factor $\mathrm{H}$ gene reveals a hot spot in short consensus repeat 20. J Am Soc Nephrol 12, 297.

Caprioli, J., Castelletti, F., Bucchioni, S., Bettinaglio, P., Bresin, E., Pianetti, G., Gamba, S., Brioschi, S., Daina, E., Remuzzi, G., Noris, M. 2003. Complement factor $\mathrm{H}$ mutations and gene polymorphisms in haemolytic uraemic syndrome: the C-257T, the A2089G and the G2881T polymorphisms are strongly associated with the disease. Hum Mol Genet 12, 3385.

Cicardi, M., Zanichelli, A. 2010. Replacement therapy with C1 esterase inhibitors for hereditary angioedema. Drugs Today (Barc) 46, 867.

Compston, A., Coles, A. 2002. Multiple sclerosis. Lancet 359, 1221.

Daina, E., Noris, M., Remuzzi, G. 2012. Eculizumab in a patient with densedeposit disease. N Engl J Med 366, 1161.

Davila, S., Wright, V.J., Khor, C.C., Sim, K.S., Binder, A., Breunis, W.B., Inwald, D., Nadel, S., Betts, H., Carrol, E.D., de Groot, R., Hermans, P.W., Hazelzet, J., Emonts, M., Lim, C.C., Kuijpers, T.W., Martinon-Torres, F., Salas, A., Zenz, W., Levin, M., Hibberd, M.L. 2010. Genome-wide association study identifies variants in the $\mathrm{CFH}$ region associated with host susceptibility to meningococcal disease. Nat Genet 42, 772. 
Delvaeye, M., Noris, M., De Vriese, A., Esmon, C.T., Esmon, N.L., Ferrell, G., Del-Favero, J., Plaisance, S., Claes, B., Lambrechts, D., Zoja, C., Remuzzi, G., Conway, E.M. 2009. Thrombomodulin mutations in atypical hemolytic- uremic syndrome. N Engl J Med 361, 345.

Dinu, V., Miller, P.L., Zhao, H. 2007. Evidence for association between multiple complement pathway genes and AMD. Genet Epidemiol 31, 224.

Dragon-Durey, M.A., Blanc, C., Marliot, F., Loirat, C., Blouin, J., SautesFridman, C., Fridman, W.H., Fremeaux-Bacchi, V. 2009. The high frequency of complement factor $\mathrm{H}$ related CFHR1 gene deletion is restricted to specific subgroups of patients with atypical haemolytic uraemic syndrome. J Med Genet 46, 447.

Dragon-Durey, M.A., Fremeaux-Bacchi, V., Loirat, C., Blouin, J., Niaudet, P., Deschenes, G., Coppo, P., Herman Fridman, W., Weiss, L. 2004. Heterozygous and homozygous factor $h$ deficiencies associated with hemolytic uremic syndrome or membranoproliferative glomerulonephritis: report and genetic analysis of 16 cases. J Am Soc Nephrol 15, 787.

Edwards, A.O., Ritter, R., 3rd, Abel, K.J., Manning, A., Panhuysen, C., Farrer, L.A. 2005. Complement factor $\mathrm{H}$ polymorphism and age-related macular degeneration. Science 308, 421.

Esparza-Gordillo, J., Goicoechea de Jorge, E., Buil, A., Carreras Berges, L., Lopez-Trascasa, M., Sanchez-Corral, P., Rodriguez de Cordoba, S. 2005. Predisposition to atypical hemolytic uremic syndrome involves the concurrence of different susceptibility alleles in the regulators of complement activation gene cluster in 1q32. Hum Mol Genet 14, 703.

Esparza-Gordillo, J., Jorge, E.G., Garrido, C.A., Carreras, L., Lopez-Trascasa, M., Sanchez-Corral, P., de Cordoba, S.R. 2006. Insights into hemolytic uremic syndrome: segregation of three independent predisposition factors in a large, multiple affected pedigree. Mol Immunol 43, 1769.

Esparza-Gordillo, J., Soria, J.M., Buil, A., Souto, J.C., Almasy, L., Blangero, J., de Cordoba, S.R., Fontcuberta, J. 2004. Genetic correlation between plasma levels of C4BP isoforms containing beta chains and susceptibility to thrombosis. J Med Genet 41, e5. 
Fagerness, J.A., Maller, J.B., Neale, B.M., Reynolds, R.C., Daly, M.J., Seddon, J.M. 2009. Variation near complement factor I is associated with risk of advanced AMD. Eur J Hum Genet 17, 100.

Fakhouri, F., Fremeaux-Bacchi, V., Noel, L.H., Cook, H.T., Pickering, M.C. 2010. C3 glomerulopathy: a new classification. Nat Rev Nephrol 6, 494.

Fang, C.J., Richards, A., Liszewski, M.K., Kavanagh, D., Atkinson, J.P. 2008. Advances in understanding of pathogenesis of aHUS and HELLP. $\mathrm{Br} J$ Haematol 143, 336.

Francis, N.J., McNicholas, B., Awan, A., Waldron, M., Reddan, D., Sadlier, D., Kavanagh, D., Strain, L., Marchbank, K.J., Harris, C.L., Goodship, T.H. 2012. A novel hybrid $\mathrm{CFH} / \mathrm{CFHR3}$ gene generated by a microhomology-mediated deletion in familial atypical hemolytic uremic syndrome. Blood 119, 591.

Fremeaux-Bacchi, V., Dragon-Durey, M.A., Blouin, J., Vigneau, C., Kuypers, D., Boudailliez, B., Loirat, C., Rondeau, E., Fridman, W.H. 2004. Complement factor I: a susceptibility gene for atypical haemolytic uraemic syndrome. J Med Genet 41, e84.

Fremeaux-Bacchi, V., Miller, E.C., Liszewski, M.K., Strain, L., Blouin, J., Brown, A.L., Moghal, N., Kaplan, B.S., Weiss, R.A., Lhotta, K., Kapur, G., Mattoo, T., Nivet, H., Wong, W., Gie, S., Hurault de Ligny, B., Fischbach, M., Gupta, R., Hauhart, R., Meunier, V., Loirat, C., Dragon-Durey, M.A., Fridman, W.H., Janssen, B.J., Goodship, T.H., Atkinson, J.P. 2008. Mutations in complement C3 predispose to development of atypical hemolytic uremic syndrome. Blood $112,4948$.

Fridkis-Hareli, M., Storek, M., Mazsaroff, I., Risitano, A.M., Lundberg, A.S., Horvath, C.J., Holers, V.M. 2011. Design and development of TT30, a novel C3d-targeted C3/C5 convertase inhibitor for treatment of human complement alternative pathway-mediated diseases. Blood 118, 4705.

Fritsche, L.G., Lauer, N., Hartmann, A., Stippa, S., Keilhauer, C.N., Oppermann, M., Pandey, M.K., Kohl, J., Zipfel, P.F., Weber, B.H., Skerka, C. 2010. An imbalance of human complement regulatory proteins CFHR1, CFHR3 and factor $\mathrm{H}$ influences risk for age-related macular degeneration (AMD). Hum Mol Genet 19, 4694. 
Gale, D.P., de Jorge, E.G., Cook, H.T., Martinez-Barricarte, R., Hadjisavvas, A., Mclean, A.G., Pusey, C.D., Pierides, A., Kyriacou, K., Athanasiou, Y., Voskarides, K., Deltas, C., Palmer, A., Fremeaux-Bacchi, V., de Cordoba, S.R., Maxwell, P.H., Pickering, M.C. 2010. Identification of a mutation in complement factor $\mathrm{H}$-related protein 5 in patients of Cypriot origin with glomerulonephritis. Lancet 376, 794.

Gale, D.P., Pickering, M.C. 2011. Regulating complement in the kidney: insights from CFHR5 nephropathy. Dis Model Mech 4, 721.

Gharavi, A.G., Kiryluk, K., Choi, M., Li, Y., Hou, P., Xie, J., Sanna-Cherchi, S., Men, C.J., Julian, B.A., Wyatt, R.J., Novak, J., He, J.C., Wang, H., Lv, J., Zhu, L., Wang, W., Wang, Z., Yasuno, K., Gunel, M., Mane, S., Umlauf, S., Tikhonova, I., Beerman, I., Savoldi, S., Magistroni, R., Ghiggeri, G.M., Bodria, M., Lugani, F., Ravani, P., Ponticelli, C., Allegri, L., Boscutti, G., Frasca, G., Amore, A., Peruzzi, L., Coppo, R., Izzi, C., Viola, B.F., Prati, E., Salvadori, M., Mignani, R., Gesualdo, L., Bertinetto, F., Mesiano, P., Amoroso, A., Scolari, F., Chen, N., Zhang, H., Lifton, R.P. 2011. Genome-wide association study identifies susceptibility loci for IgA nephropathy. Nat Genet 43, 321.

Goicoechea de Jorge, E., Harris, C.L., Esparza-Gordillo, J., Carreras, L., Arranz, E.A., Garrido, C.A., Lopez-Trascasa, M., Sanchez-Corral, P., Morgan, B.P., Rodriguez de Cordoba, S. 2007. Gain-of-function mutations in complement factor B are associated with atypical hemolytic uremic syndrome. Proc Natl Acad Sci U S A 104, 240.

Gold, B., Merriam, J.E., Zernant, J., Hancox, L.S., Taiber, A.J., Gehrs, K., Cramer, K., Neel, J., Bergeron, J., Barile, G.R., Smith, R.T., Hageman, G.S., Dean, M., Allikmets, R. 2006. Variation in factor B (BF) and complement component 2 (C2) genes is associated with age-related macular degeneration. Nat Genet 38, 458.

Gorin, M.B. 2012. Genetic insights into age-related macular degeneration: Controversies addressing risk, causality, and therapeutics. Mol Aspects Med.

Hageman, G.S., Anderson, D.H., Johnson, L.V., Hancox, L.S., Taiber, A.J., Hardisty, L.I., Hageman, J.L., Stockman, H.A., Borchardt, J.D., Gehrs, K.M., Smith, R.J., Silvestri, G., Russell, S.R., Klaver, C.C., Barbazetto, I., Chang, 
S., Yannuzzi, L.A., Barile, G.R., Merriam, J.C., Smith, R.T., Olsh, A.K., Bergeron, J., Zernant, J., Merriam, J.E., Gold, B., Dean, M., Allikmets, R. 2005. A common haplotype in the complement regulatory gene factor $\mathrm{H}$ (HF1/CFH) predisposes individuals to age-related macular degeneration. Proc Natl Acad Sci U S A 102, 7227.

Hageman, G.S., Hancox, L.S., Taiber, A.J., Gehrs, K.M., Anderson, D.H., Johnson, L.V., Radeke, M.J., Kavanagh, D., Richards, A., Atkinson, J., Meri, S., Bergeron, J., Zernant, J., Merriam, J., Gold, B., Allikmets, R., Dean, M. 2006. Extended haplotypes in the complement factor $\mathrm{H}(\mathrm{CFH})$ and $\mathrm{CFH}$ related (CFHR) family of genes protect against age-related macular degeneration: characterization, ethnic distribution and evolutionary implications. Ann Med 38, 592.

Hageman, G.S., Mullins, R.F. 1999. Molecular composition of drusen as related to substructural phenotype. Mol Vis 5, 28.

Haines, J.L., Hauser, M.A., Schmidt, S., Scott, W.K., Olson, L.M., Gallins, P., Spencer, K.L., Kwan, S.Y., Noureddine, M., Gilbert, J.R., Schnetz-Boutaud, N., Agarwal, A., Postel, E.A., Pericak-Vance, M.A. 2005. Complement factor $\mathrm{H}$ variant increases the risk of age-related macular degeneration. Science $308,419$.

Hakobyan, S., Tortajada, A., Harris, C.L., de Cordoba, S.R., Morgan, B.P. 2010. Variant-specific quantification of factor $\mathrm{H}$ in plasma identifies null alleles associated with atypical hemolytic uremic syndrome. Kidney Int 78, 782.

Haralambous, E., Dolly, S.O., Hibberd, M.L., Litt, D.J., Udalova, I.A., O'Dwyer, C., Langford, P.R., Simon Kroll, J., Levin, M. 2006. Factor H, a regulator of complement activity, is a major determinant of meningococcal disease susceptibility in UK Caucasian patients. Scand J Infect Dis 38, 764.

Harris, C.L., Heurich, M., Rodriguez de Cordoba, S., Morgan, B.P. 2012. The complotype: dictating risk for inflammation and infection. Trends Immunol (In press).

Hebecker, M., Jozsi, M. 2012. Factor H-related Protein 4 Activates Complement by Serving as a Platform for the Assembly of Alternative Pathway C3 Convertase via Its Interaction with C3b Protein. J Biol Chem 287, 19528. 
Hecker, L.A., Edwards, A.O., Ryu, E., Tosakulwong, N., Baratz, K.H., Brown, W.L., Charbel Issa, P., Scholl, H.P., Pollok-Kopp, B., Schmid-Kubista, K.E., Bailey, K.R., Oppermann, M. 2010. Genetic control of the alternative pathway of complement in humans and age-related macular degeneration. Hum Mol Genet 19, 209.

Heinen, S., Hartmann, A., Lauer, N., Wiehl, U., Dahse, H.M., Schirmer, S., Gropp, K., Enghardt, T., Wallich, R., Halbich, S., Mihlan, M., SchlotzerSchrehardt, U., Zipfel, P.F., Skerka, C. 2009. Factor H-related protein 1 (CFHR-1) inhibits complement C5 convertase activity and terminal complex formation. Blood 114, 2439.

Hellwage, J., Jokiranta, T.S., Koistinen, V., Vaarala, O., Meri, S., Zipfel, P.F. 1999. Functional properties of complement factor H-related proteins FHR-3 and FHR-4: binding to the C3d region of $\mathrm{C} 3 \mathrm{~b}$ and differential regulation by heparin. FEBS Lett 462, 345.

Heurich, M., Martinez-Barricarte, R., Francis, N.J., Roberts, D.L., Rodriguez de Cordoba, S., Morgan, B.P., Harris, C.L. 2011. Common polymorphisms in C3, factor $\mathrm{B}$, and factor $\mathrm{H}$ collaborate to determine systemic complement activity and disease risk. Proc Natl Acad Sci U S A 108, 8761.

Hogasen, K., Jansen, J.H., Mollnes, T.E., Hovdenes, J., Harboe, M. 1995. Hereditary porcine membranoproliferative glomerulonephritis type II is caused by factor H deficiency. J Clin Invest 95, 1054.

Hughes, A.E., Orr, N., Esfandiary, H., Diaz-Torres, M., Goodship, T., Chakravarthy, U. 2006. A common CFH haplotype, with deletion of CFHR1 and CFHR3, is associated with lower risk of age-related macular degeneration. Nat Genet 38, 1173.

Ingram, G., Hakobyan, S., Hirst, C., Harris, C., Loveless, S., Mitchell, J., Pickersgill, T., Robertson, N., Morgan, B. 2012. Systemic complement profiling in multiple sclerosis as a biomarker of disease state. Mult Scler.

Ingram, G., Hakobyan, S., Hirst, C.L., Harris, C.L., Pickersgill, T.P., Cossburn, M.D., Loveless, S., Robertson, N.P., Morgan, B.P. 2010. Complement regulator factor $\mathrm{H}$ as a serum biomarker of multiple sclerosis disease state. Brain 133, 1602. 
Ingram, G., Hakobyan, S., Robertson, N.P., Morgan, B.P. 2009. Complement in multiple sclerosis: its role in disease and potential as a biomarker. Clin Exp Immunol 155, 128.

Ingram, G., Hakobyan, S., Robertson, N.P., Morgan, B.P. 2010. Elevated plasma $\mathrm{C} 4 \mathrm{a}$ levels in multiple sclerosis correlate with disease activity. $\mathrm{J}$ Neuroimmunol 223, 124.

Jozsi, M., Licht, C., Strobel, S., Zipfel, S.L., Richter, H., Heinen, S., Zipfel, P.F., Skerka, C. 2008. Factor $\mathrm{H}$ autoantibodies in atypical hemolytic uremic syndrome correlate with CFHR1/CFHR3 deficiency. Blood 111, 1512.

Jozsi, M., Zipfel, P.F. 2008. Factor H family proteins and human diseases. Trends Immunol 29, 380.

Kavanagh, D., Kemp, E.J., Mayland, E., Winney, R.J., Duffield, J.S., Warwick, G., Richards, A., Ward, R., Goodship, J.A., Goodship, T.H. 2005. Mutations in complement factor I predispose to development of atypical hemolytic uremic syndrome. J Am Soc Nephrol 16, 2150.

Kemper, C., Atkinson, J.P., Hourcade, D.E. 2010. Properdin: emerging roles of a pattern-recognition molecule. Annu Rev Immunol 28, 131.

Klein, R.J., Zeiss, C., Chew, E.Y., Tsai, J.Y., Sackler, R.S., Haynes, C., Henning, A.K., SanGiovanni, J.P., Mane, S.M., Mayne, S.T., Bracken, M.B., Ferris, F.L., Ott, J., Barnstable, C., Hoh, J. 2005. Complement factor H polymorphism in age-related macular degeneration. Science 308, 385.

Lachmann, P.J. 2009. The amplification loop of the complement pathways. Adv Immunol 104, 115.

Landau, D., Shalev, H., Levy-Finer, G., Polonsky, A., Segev, Y., Katchko, L. 2001. Familial hemolytic uremic syndrome associated with complement factor $\mathrm{H}$ deficiency. J Pediatr 138, 412.

Lassmann, H. 2004. Recent neuropathological findings in MS--implications for diagnosis and therapy. J Neurol 251 Suppl 4, IV2.

Levy, M., Halbwachs-Mecarelli, L., Gubler, M.C., Kohout, G., Bensenouci, A., Niaudet, P., Hauptmann, G., Lesavre, P. 1986. H deficiency in two brothers with atypical dense intramembranous deposit disease. Kidney Int 30, 949. 
Licht, C., Heinen, S., Jozsi, M., Loschmann, I., Saunders, R.E., Perkins, S.J., Waldherr, R., Skerka, C., Kirschfink, M., Hoppe, B., Zipfel, P.F. 2006. Deletion of Lys224 in regulatory domain 4 of Factor $\mathrm{H}$ reveals a novel pathomechanism for dense deposit disease (MPGN II). Kidney Int 70, 42.

Linington, C., Morgan, B.P., Scolding, N.J., Wilkins, P., Piddlesden, S., Compston, D.A. 1989. The role of complement in the pathogenesis of experimental allergic encephalomyelitis. Brain 112 ( Pt 4), 895.

Liszewski, M.K., Leung, M.K., Schraml, B., Goodship, T.H., Atkinson, J.P. 2007. Modeling how CD46 deficiency predisposes to atypical hemolytic uremic syndrome. Mol Immunol 44, 1559.

Lucchinetti, C., Bruck, W., Parisi, J., Scheithauer, B., Rodriguez, M., Lassmann, H. 2000. Heterogeneity of multiple sclerosis lesions: implications for the pathogenesis of demyelination. Ann Neurol 47, 707.

Mache, C.J., Acham-Roschitz, B., Fremeaux-Bacchi, V., Kirschfink, M., Zipfel, P.F., Roedl, S., Vester, U., Ring, E. 2009. Complement inhibitor eculizumab in atypical hemolytic uremic syndrome. Clin J Am Soc Nephrol 4, 1312.

Malik, T.H., Lavin, P.J., Goicoechea de Jorge, E., Vernon, K.A., Rose, K.L., Patel, M.P., de Leeuw, M., Neary, J.J., Conlon, P.J., Winn, M.P., Pickering, M.C. 2012. A Hybrid CFHR3-1 Gene Causes Familial C3 Glomerulopathy. J Am Soc Nephrol.

Maller, J., George, S., Purcell, S., Fagerness, J., Altshuler, D., Daly, M.J., Seddon, J.M. 2006. Common variation in three genes, including a noncoding variant in $\mathrm{CFH}$, strongly influences risk of age-related macular degeneration. Nat Genet 38, 1055.

Manuelian, T., Hellwage, J., Meri, S., Caprioli, J., Noris, M., Heinen, S., Jozsi, M., Neumann, H.P., Remuzzi, G., Zipfel, P.F. 2003. Mutations in factor H reduce binding affinity to $\mathrm{C} 3 \mathrm{~b}$ and heparin and surface attachment to endothelial cells in hemolytic uremic syndrome. J Clin Invest 111, 1181.

Martinez-Barricarte, R., Heurich, M., Valdes-Canedo, F., Vazquez-Martul, E., Torreira, E., Montes, T., Tortajada, A., Pinto, S., Lopez-Trascasa, M., Morgan, B.P., Llorca, O., Harris, C.L., Rodriguez de Cordoba, S. 2010. Human C3 
mutation reveals a mechanism of dense deposit disease pathogenesis and provides insights into complement activation and regulation. J Clin Invest 120, 3702.

Martinez-Barricarte, R., Pianetti, G., Gautard, R., Misselwitz, J., Strain, L., Fremeaux-Bacchi, V., Skerka, C., Zipfel, P.F., Goodship, T., Noris, M., Remuzzi, G., de Cordoba, S.R. 2008. The complement factor H R1210C mutation is associated with atypical hemolytic uremic syndrome. J Am Soc Nephrol 19, 639.

Martinez-Barricarte, R., Recalde, S., Fernandez-Robredo, P., Millan, I., Olavarrieta, L., Vinuela, A., Perez-Perez, J., Garcia-Layana, A., Rodriguez de Cordoba, S. 2012. Relevance of Complement Factor H-Related 1 (CFHR1) Genotypes in Age-Related Macular Degeneration. Invest Ophthalmol Vis Sci $53,1087$.

McRae, J.L., Duthy, T.G., Griggs, K.M., Ormsby, R.J., Cowan, P.J., Cromer, B.A., McKinstry, W.J., Parker, M.W., Murphy, B.F., Gordon, D.L. 2005. Human factor $\mathrm{H}$-related protein 5 has cofactor activity, inhibits $\mathrm{C} 3$ convertase activity, binds heparin and C-reactive protein, and associates with lipoprotein. J Immunol 174, 6250.

Monteferrante, G., Brioschi, S., Caprioli, J., Pianetti, G., Bettinaglio, P., Bresin, E., Remuzzi, G., Noris, M. 2007. Genetic analysis of the complement factor $\mathrm{H}$ related 5 gene in haemolytic uraemic syndrome. Mol Immunol 44, 1704.

Montes, T., Tortajada, A., Morgan, B.P., Rodriguez de Cordoba, S., Harris, C.L. 2009. Functional basis of protection against age-related macular degeneration conferred by a common polymorphism in complement factor B. Proc Natl Acad Sci U S A 106, 4366.

Moore, I., Strain, L., Pappworth, I., Kavanagh, D., Barlow, P.N., Herbert, A.P., Schmidt, C.Q., Staniforth, S.J., Holmes, L.V., Ward, R., Morgan, L., Goodship, T.H., Marchbank, K.J. 2010. Association of factor H autoantibodies with deletions of CFHR1, CFHR3, CFHR4, and with mutations in $\mathrm{CFH}, \mathrm{CFI}, \mathrm{CD} 46$, and $\mathrm{C} 3$ in patients with atypical hemolytic uremic syndrome. Blood 115, 379. 
Morariu, M.A., Dalmasso, A.P. 1978. Experimental allergic encephalomyelitis in cobra venom factor-treated and C4-deficient guinea pigs. Ann Neurol 4, 427.

Muller-Eberhard, H.J. 1985. The killer molecule of complement. J Invest Dermatol 85, 47s.

Narendra, U., Pauer, G.J., Hagstrom, S.A. 2009. Genetic analysis of complement factor $\mathrm{H}$ related 5, CFHR5, in patients with age-related macular degeneration. Mol Vis 15, 731.

Neumann, H.P., Salzmann, M., Bohnert-Iwan, B., Mannuelian, T., Skerka, C., Lenk, D., Bender, B.U., Cybulla, M., Riegler, P., Konigsrainer, A., Neyer, U., Bock, A., Widmer, U., Male, D.A., Franke, G., Zipfel, P.F. 2003. Haemolytic uraemic syndrome and mutations of the factor $\mathrm{H}$ gene: a registry-based study of German speaking countries. J Med Genet 40, 676.

Noris, M., Brioschi, S., Caprioli, J., Todeschini, M., Bresin, E., Porrati, F., Gamba, S., Remuzzi, G. 2003. Familial haemolytic uraemic syndrome and an MCP mutation. Lancet 362, 1542.

Noris, M., Remuzzi, G. 2005. Hemolytic uremic syndrome. J Am Soc Nephrol 16, 1035.

Nurnberger, J., Philipp, T., Witzke, O., Opazo Saez, A., Vester, U., Baba, H.A., Kribben, A., Zimmerhackl, L.B., Janecke, A.R., Nagel, M., Kirschfink, M. 2009. Eculizumab for atypical hemolytic-uremic syndrome. N Engl J Med 360, 542.

Ohali, M., Shalev, H., Schlesinger, M., Katz, Y., Kachko, L., Carmi, R., Sofer, S., Landau, D. 1998. Hypocomplementemic autosomal recessive hemolytic uremic syndrome with decreased factor H. Pediatr Nephrol 12, 619.

Pangburn, M.K., Schreiber, R.D., Muller-Eberhard, H.J. 1981. Formation of the initial C3 convertase of the alternative complement pathway. Acquisition of C3b-like activities by spontaneous hydrolysis of the putative thioester in native C3. J Exp Med 154, 856.

Perez-Caballero, D., Gonzalez-Rubio, C., Gallardo, M.E., Vera, M., LopezTrascasa, M., Rodriguez de Cordoba, S., Sanchez-Corral, P. 2001. Clustering of missense mutations in the $\mathrm{C}$-terminal region of factor $\mathrm{H}$ in atypical hemolytic uremic syndrome. Am J Hum Genet 68, 478. 
Pickering, M.C., Cook, H.T., Warren, J., Bygrave, A.E., Moss, J., Walport, M.J., Botto, M. 2002. Uncontrolled C3 activation causes membranoproliferative glomerulonephritis in mice deficient in complement factor $\mathrm{H}$. Nat Genet 31 , 424.

Pickering, M.C., de Jorge, E.G., Martinez-Barricarte, R., Recalde, S., GarciaLayana, A., Rose, K.L., Moss, J., Walport, M.J., Cook, H.T., de Cordoba, S.R., Botto, M. 2007. Spontaneous hemolytic uremic syndrome triggered by complement factor $\mathrm{H}$ lacking surface recognition domains. J Exp Med 204, 1249.

Raychaudhuri, S., lartchouk, O., Chin, K., Tan, P.L., Tai, A.K., Ripke, S., Gowrisankar, S., Vemuri, S., Montgomery, K., Yu, Y., Reynolds, R., Zack, D.J., Campochiaro, B., Campochiaro, P., Katsanis, N., Daly, M.J., Seddon, J.M. 2011. A rare penetrant mutation in $\mathrm{CFH}$ confers high risk of age-related macular degeneration. Nat Genet 43, 1232.

Reynolds, R., Hartnett, M.E., Atkinson, J.P., Giclas, P.C., Rosner, B., Seddon, J.M. 2009. Plasma complement components and activation fragments: associations with age-related macular degeneration genotypes and phenotypes. Invest Ophthalmol Vis Sci 50, 5818.

Ricklin, D., Hajishengallis, G., Yang, K., Lambris, J.D. 2010. Complement: a key system for immune surveillance and homeostasis. Nat Immunol 11, 785.

Richards, A., Buddles, M.R., Donne, R.L., Kaplan, B.S., Kirk, E., Venning, M.C., Tielemans, C.L., Goodship, J.A., Goodship, T.H. 2001. Factor H mutations in hemolytic uremic syndrome cluster in exons 18-20, a domain important for host cell recognition. Am J Hum Genet 68, 485.

Richards, A., Kemp, E.J., Liszewski, M.K., Goodship, J.A., Lampe, A.K., Decorte, R., Muslumanoglu, M.H., Kavukcu, S., Filler, G., Pirson, Y., Wen, L.S., Atkinson, J.P., Goodship, T.H. 2003. Mutations in human complement regulator, membrane cofactor protein (CD46), predispose to development of familial hemolytic uremic syndrome. Proc Natl Acad Sci U S A 100, 12966.

Risitano, A.M., Notaro, R., Marando, L., Serio, B., Ranaldi, D., Seneca, E., Ricci, P., Alfinito, F., Camera, A., Gianfaldoni, G., Amendola, A., Boschetti, C., Di Bona, E., Fratellanza, G., Barbano, F., Rodeghiero, F., Zanella, A., Iori, A.P., 
Selleri, C., Luzzatto, L., Rotoli, B. 2009. Complement fraction 3 binding on erythrocytes as additional mechanism of disease in paroxysmal nocturnal hemoglobinuria patients treated by eculizumab. Blood 113, 4094.

Rodriguez de Cordoba, S., Esparza-Gordillo, J., Goicoechea de Jorge, E., Lopez-Trascasa, M., Sanchez-Corral, P. 2004. The human complement factor $\mathrm{H}$ : functional roles, genetic variations and disease associations. Mol Immunol 41, 355.

Rose, K.L., Paixao-Cavalcante, D., Fish, J., Manderson, A.P., Malik, T.H., Bygrave, A.E., Lin, T., Sacks, S.H., Walport, M.J., Cook, H.T., Botto, M., Pickering, M.C. 2008. Factor $I$ is required for the development of membranoproliferative glomerulonephritis in factor $\mathrm{H}$-deficient mice. J Clin Invest 118, 608 .

Rother, R.P., Rollins, S.A., Mojcik, C.F., Brodsky, R.A., Bell, L. 2007. Discovery and development of the complement inhibitor eculizumab for the treatment of paroxysmal nocturnal hemoglobinuria. Nat Biotechnol 25, 1256.

Roumenina, L.T., Frimat, M., Miller, E.C., Provot, F., Dragon-Durey, M.A., Bordereau, P., Bigot, S., Hue, C., Satchell, S.C., Mathieson, P.W., Mousson, C., Noel, C., Sautes-Fridman, C., Halbwachs-Mecarelli, L., Atkinson, J.P., Lionet, A., Fremeaux-Bacchi, V. 2012. A prevalent C3 mutation in aHUS patients causes a direct C3 convertase gain of function. Blood 119, 4182 .

Sanchez-Corral, P., Criado Garcia, O., Rodriguez de Cordoba, S. 1995. Isoforms of human C4b-binding protein. I. Molecular basis for the C4BP isoform pattern and its variations in human plasma. J Immunol 155, 4030.

Sanchez-Corral, P., Gonzalez-Rubio, C., Rodriguez de Cordoba, S., LopezTrascasa, M. 2004. Functional analysis in serum from atypical Hemolytic Uremic Syndrome patients reveals impaired protection of host cells associated with mutations in factor $\mathrm{H}$. Mol Immunol 41, 81 .

Sanchez-Corral, P., Perez-Caballero, D., Huarte, O., Simckes, A.M., Goicoechea, E., Lopez-Trascasa, M., de Cordoba, S.R. 2002. Structural and functional characterization of factor $\mathrm{H}$ mutations associated with atypical hemolytic uremic syndrome. Am J Hum Genet 71, 1285. 
Scholl, H.P., Charbel Issa, P., Walier, M., Janzer, S., Pollok-Kopp, B., Borncke, F., Fritsche, L.G., Chong, N.V., Fimmers, R., Wienker, T., Holz, F.G., Weber, B.H., Oppermann, M. 2008. Systemic complement activation in age-related macular degeneration. PLoS One 3, e2593.

Servais, A., Noel, L.H., Roumenina, L.T., Le Quintrec, M., Ngo, S., DragonDurey, M.A., Macher, M.A., Zuber, J., Karras, A., Provot, F., Moulin, B., Grunfeld, J.P., Niaudet, P., Lesavre, P., Fremeaux-Bacchi, V. 2012. Acquired and genetic complement abnormalities play a critical role in dense deposit disease and other C3 glomerulopathies. Kidney Int. Mar 28 (Epub ahead of print).

Skerka, C., Zipfel, P.F. 2008. Complement factor $\mathrm{H}$ related proteins in immune diseases. Vaccine 26 Suppl 8, 19.

Smailhodzic, D., Klaver, C.C., Klevering, B.J., Boon, C.J., Groenewoud, J.M., Kirchhof, B., Daha, M.R., den Hollander, A.I., Hoyng, C.B. 2012. Risk alleles in CFH and ARMS2 are independently associated with systemic complement activation in age-related macular degeneration. Ophthalmology 119, 339.

Smith, R.J., Alexander, J., Barlow, P.N., Botto, M., Cassavant, T.L., Cook, H.T., de Cordoba, S.R., Hageman, G.S., Jokiranta, T.S., Kimberling, W.J., Lambris, J.D., Lanning, L.D., Levidiotis, V., Licht, C., Lutz, H.U., Meri, S., Pickering, M.C., Quigg, R.J., Rops, A.L., Salant, D.J., Sethi, S., Thurman, J.M., Tully, H.F., Tully, S.P., van der Vlag, J., Walker, P.D., Wurzner, R., Zipfel, P.F. 2007. New approaches to the treatment of dense deposit disease. J Am Soc Nephrol 18, 2447.

Smith, R.J., Harris, C.L., Pickering, M.C. 2011. Dense deposit disease. Mol Immunol 48, 1604.

Takeda, J., Miyata, T., Kawagoe, K., lida, Y., Endo, Y., Fujita, T., Takahashi, M., Kitani, T., Kinoshita, T. 1993. Deficiency of the GPI anchor caused by a somatic mutation of the PIG-A gene in paroxysmal nocturnal hemoglobinuria. Cell 73, 703.

Tortajada, A., Montes, T., Martinez-Barricarte, R., Morgan, B.P., Harris, C.L., de Cordoba, S.R. 2009. The disease-protective complement factor $\mathrm{H}$ allotypic 
variant lle62 shows increased binding affinity for C3b and enhanced cofactor activity. Hum Mol Genet 18, 3452.

Tortajada, A., Pinto, S., Martinez-Ara, J., Lopez-Trascasa, M., Sanchez-Corral, P., de Cordoba, S.R. 2012. Complement factor H variants 1890 and L1007 while commonly associated with atypical hemolytic uremic syndrome are polymorphisms with no functional significance. Kidney Int 81, 56.

Veerhuis, R., Nielsen, H.M., Tenner, A.J. 2011. Complement in the brain. Mol Immunol 48, 1592.

Venables, J.P., Strain, L., Routledge, D., Bourn, D., Powell, H.M., Warwicker, P., Diaz-Torres, M.L., Sampson, A., Mead, P., Webb, M., Pirson, Y., Jackson, M.S., Hughes, A., Wood, K.M., Goodship, J.A., Goodship, T.H. 2006. Atypical haemolytic uraemic syndrome associated with a hybrid complement gene. PLoS Med 3, e431.

Vivarelli, M., Pasini, A., Emma, F. 2012. Eculizumab for the treatment of densedeposit disease. N Engl J Med 366, 1163.

Warwicker, P., Goodship, T.H., Donne, R.L., Pirson, Y., Nicholls, A., Ward, R.M., Turnpenny, P., Goodship, J.A. 1998. Genetic studies into inherited and sporadic hemolytic uremic syndrome. Kidney Int 53, 836.

Weismann, D., Hartvigsen, K., Lauer, N., Bennett, K.L., Scholl, H.P., Charbel Issa, P., Cano, M., Brandstatter, H., Tsimikas, S., Skerka, C., Superti-Furga, G., Handa, J.T., Zipfel, P.F., Witztum, J.L., Binder, C.J. 2011. Complement factor $\mathrm{H}$ binds malondialdehyde epitopes and protects from oxidative stress. Nature 478, 76.

Woehrl, B., Brouwer, M.C., Murr, C., Heckenberg, S.G., Baas, F., Pfister, H.W., Zwinderman, A.H., Morgan, B.P., Barnum, S.R., van der Ende, A., Koedel, U., van de Beek, D. 2011. Complement component 5 contributes to poor disease outcome in humans and mice with pneumococcal meningitis. J Clin Invest $121,3943$.

Yates, J.R., Sepp, T., Matharu, B.K., Khan, J.C., Thurlby, D.A., Shahid, H., Clayton, D.G., Hayward, C., Morgan, J., Wright, A.F., Armbrecht, A.M., Dhillon, B., Deary, I.J., Redmond, E., Bird, A.C., Moore, A.T. 2007. 
Complement C3 variant and the risk of age-related macular degeneration. $\mathrm{N}$ Engl J Med 357, 553.

Zhao, J., Wu, H., Khosravi, M., Cui, H., Qian, X., Kelly, J.A., Kaufman, K.M., Langefeld, C.D., Williams, A.H., Comeau, M.E., Ziegler, J.T., Marion, M.C., Adler, A., Glenn, S.B., Alarcon-Riquelme, M.E., Pons-Estel, B.A., Harley, J.B., Bae, S.C., Bang, S.Y., Cho, S.K., Jacob, C.O., Vyse, T.J., Niewold, T.B., Gaffney, P.M., Moser, K.L., Kimberly, R.P., Edberg, J.C., Brown, E.E., Alarcon, G.S., Petri, M.A., Ramsey-Goldman, R., Vila, L.M., Reveille, J.D., James, J.A., Gilkeson, G.S., Kamen, D.L., Freedman, B.I., Anaya, J.M., Merrill, J.T., Criswell, L.A., Scofield, R.H., Stevens, A.M., Guthridge, J.M., Chang, D.M., Song, Y.W., Park, J.A., Lee, E.Y., Boackle, S.A., Grossman, J.M., Hahn, B.H., Goodship, T.H., Cantor, R.M., Yu, C.Y., Shen, N., Tsao, B.P. 2011. Association of genetic variants in complement factor $\mathrm{H}$ and factor H-related genes with systemic lupus erythematosus susceptibility. PLoS Genet 7, e1002079.

Zipfel, P.F., Edey, M., Heinen, S., Jozsi, M., Richter, H., Misselwitz, J., Hoppe, B., Routledge, D., Strain, L., Hughes, A.E., Goodship, J.A., Licht, C., Goodship, T.H., Skerka, C. 2007. Deletion of complement factor H-related genes CFHR1 and CFHR3 is associated with atypical hemolytic uremic syndrome. PLoS Genet 3, e41.

Zipfel, P.F., Jokiranta, T.S., Hellwage, J., Koistinen, V., Meri, S. 1999. The factor $\mathrm{H}$ protein family. Immunopharmacology 42, 53. 


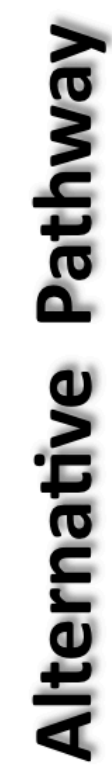
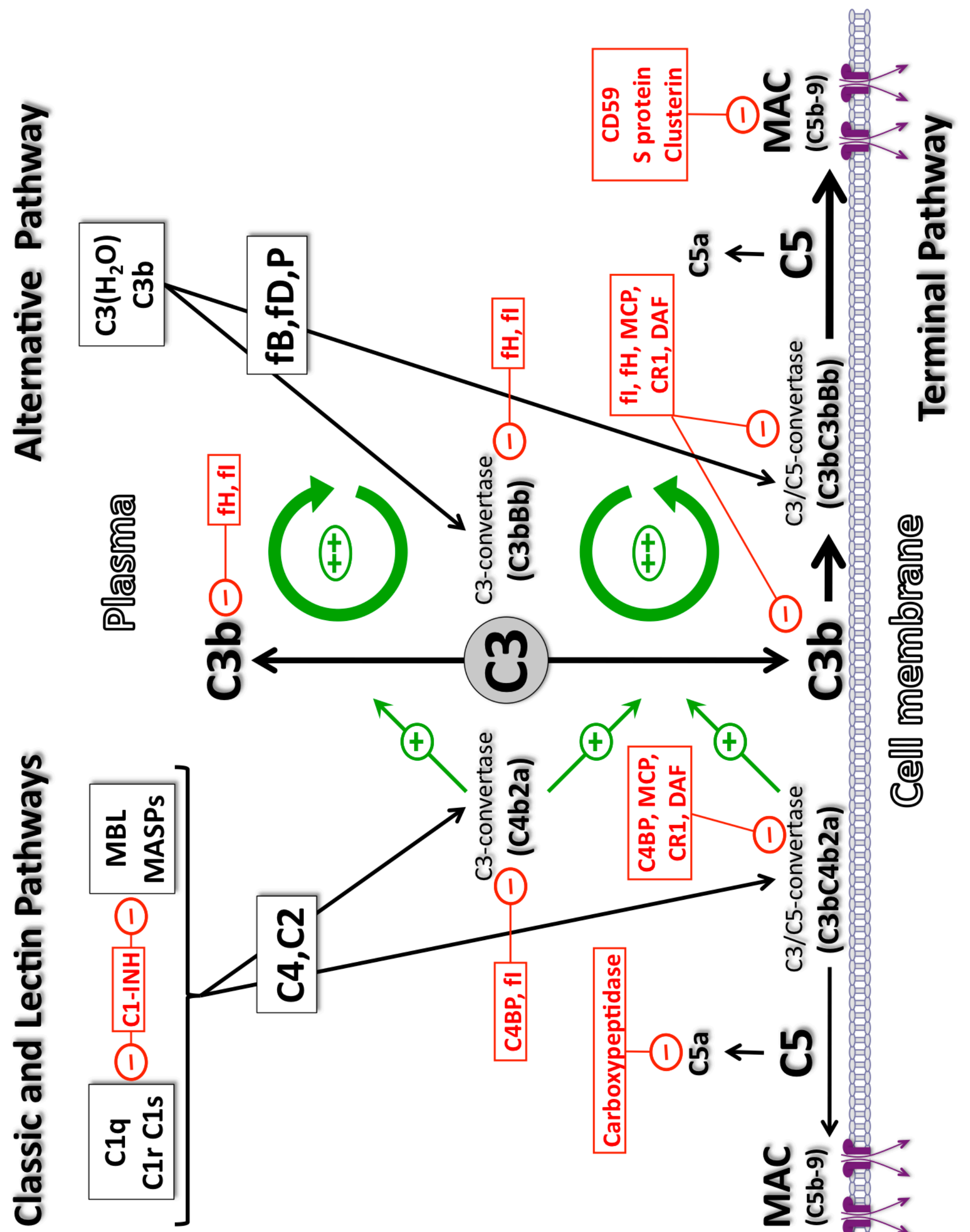

धૈ
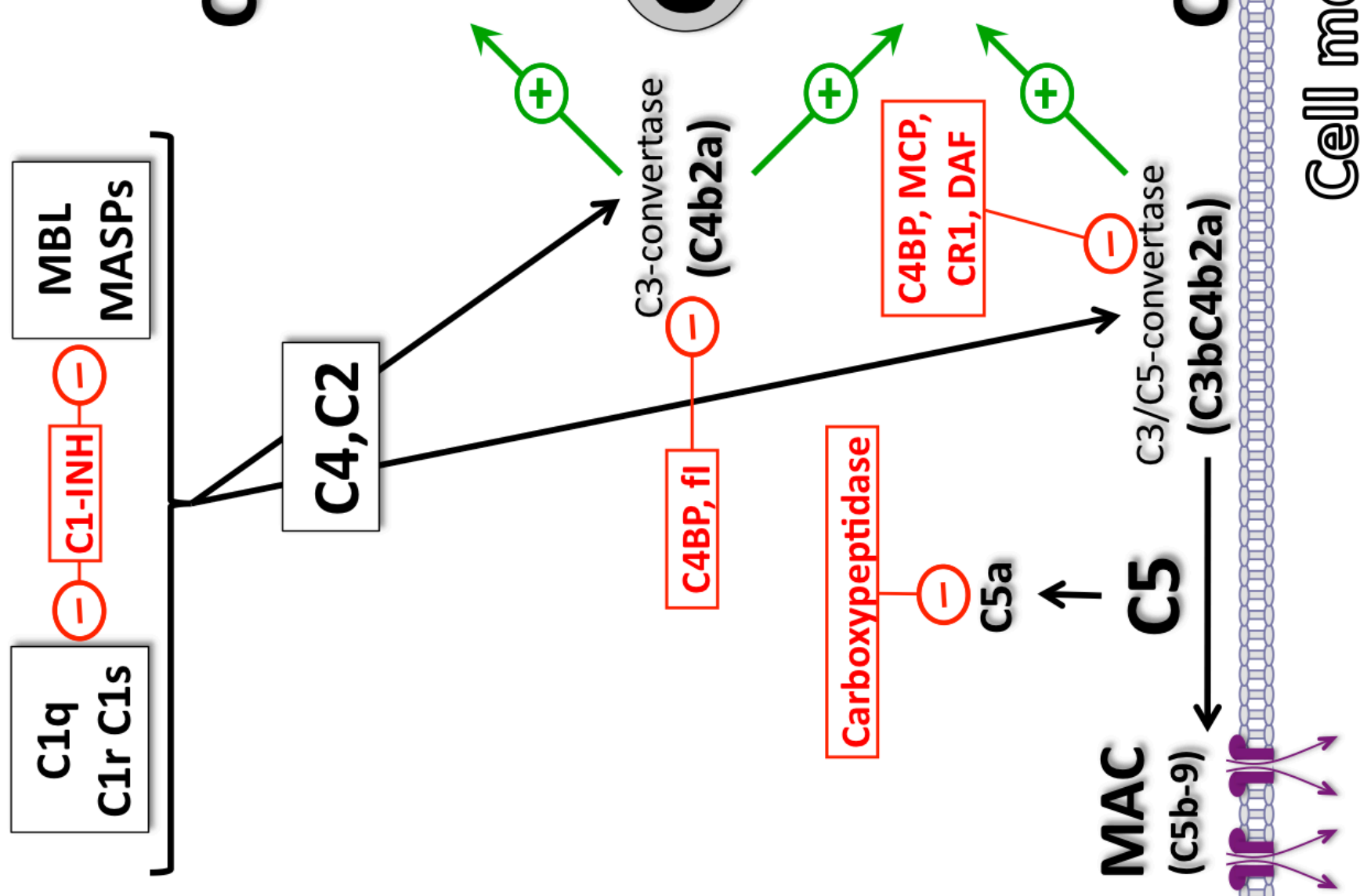


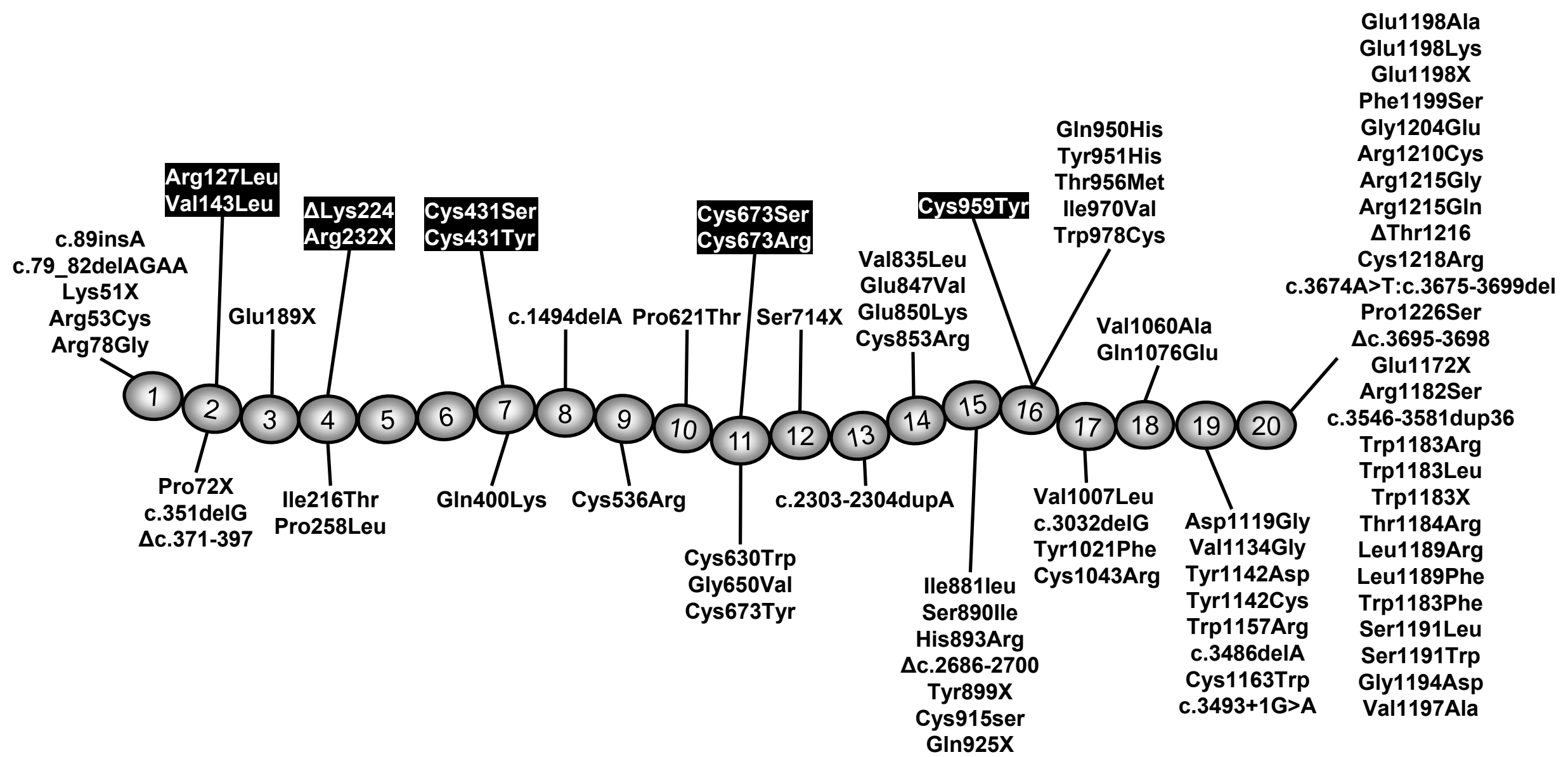


Figure 3

ํㅡㅁ

ํㅡㅁ

음

음
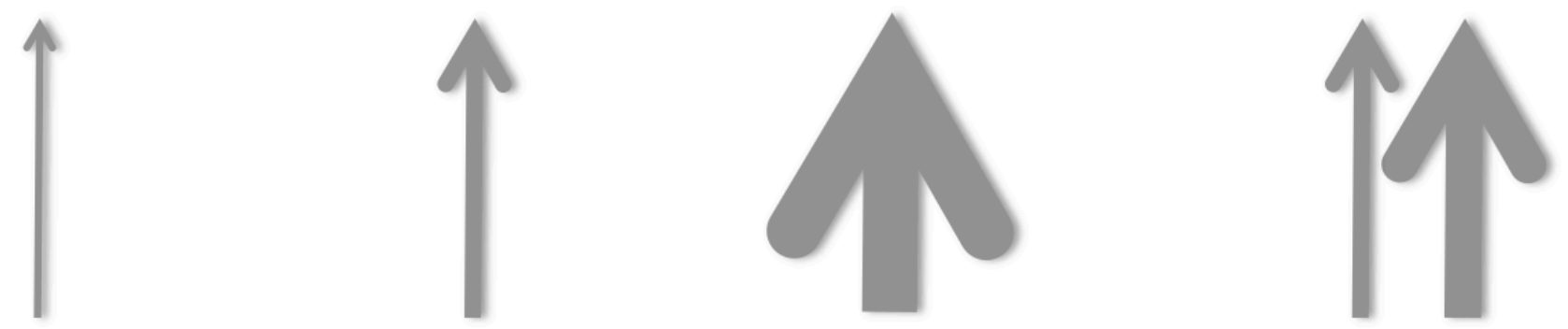

을

음

ํํํ

ํํ
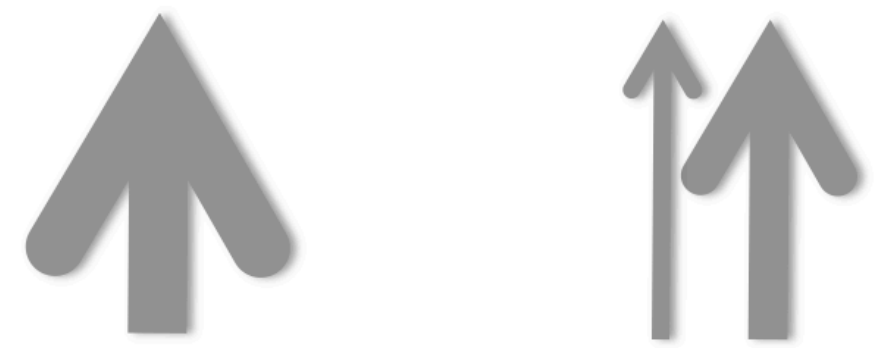

함
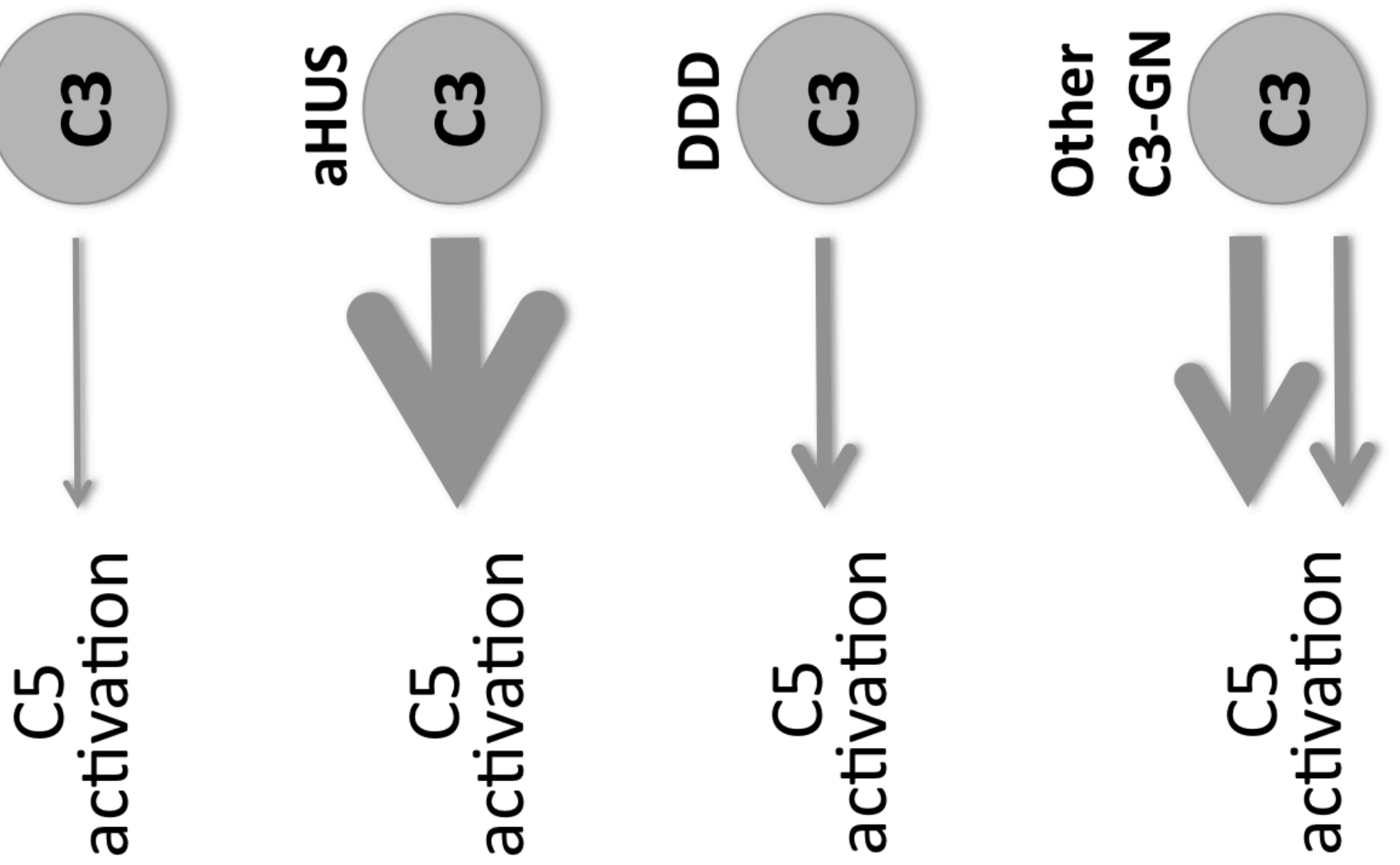
A
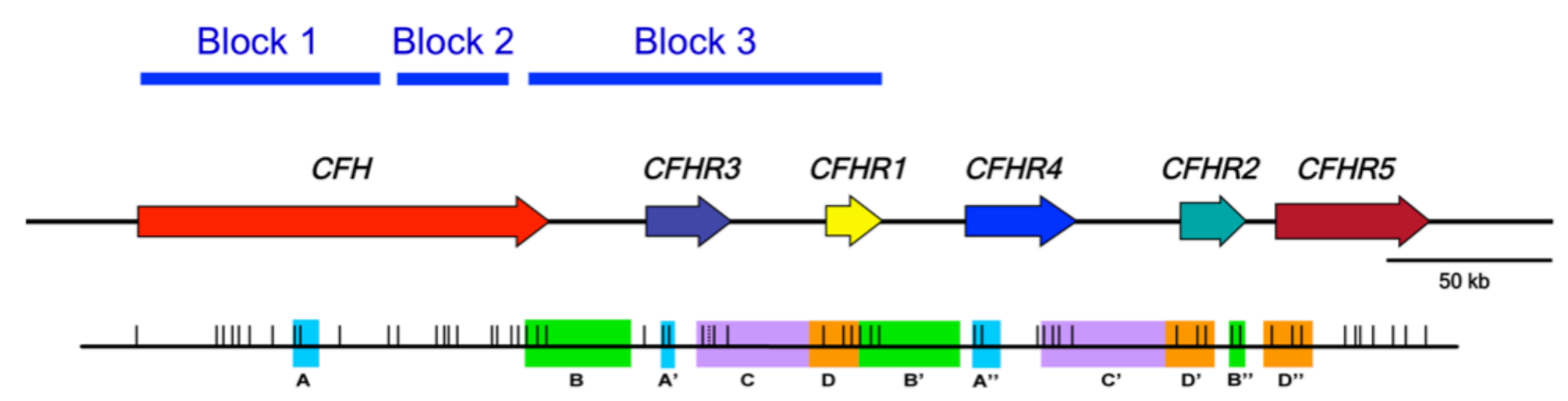

B

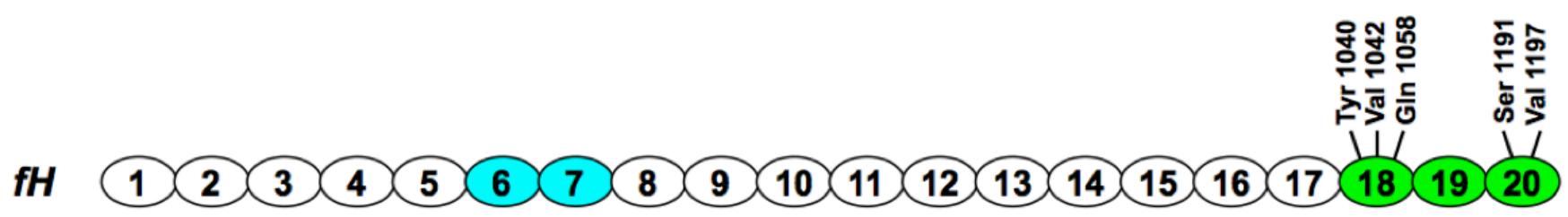

FHR-1*A

(1) 2

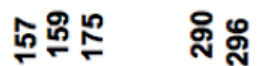

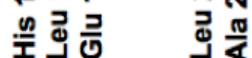

3 (4)

도융용

ธิจ

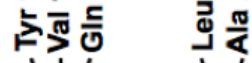

$F H R-1{ }^{*} B$

3 ( 5

FHR-2

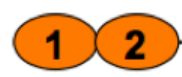

(3) 4

FHR-3

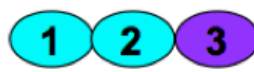

FHR-4A

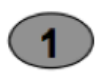

(2) 3

4

(5)......6 7

89

FHR-4B

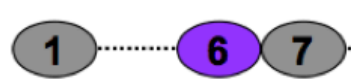

89

FHR-5

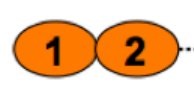

(3) 4567

89 
TABLE 1. Risk factors associated with aHUS, C3-Glomerulopathies and AMD

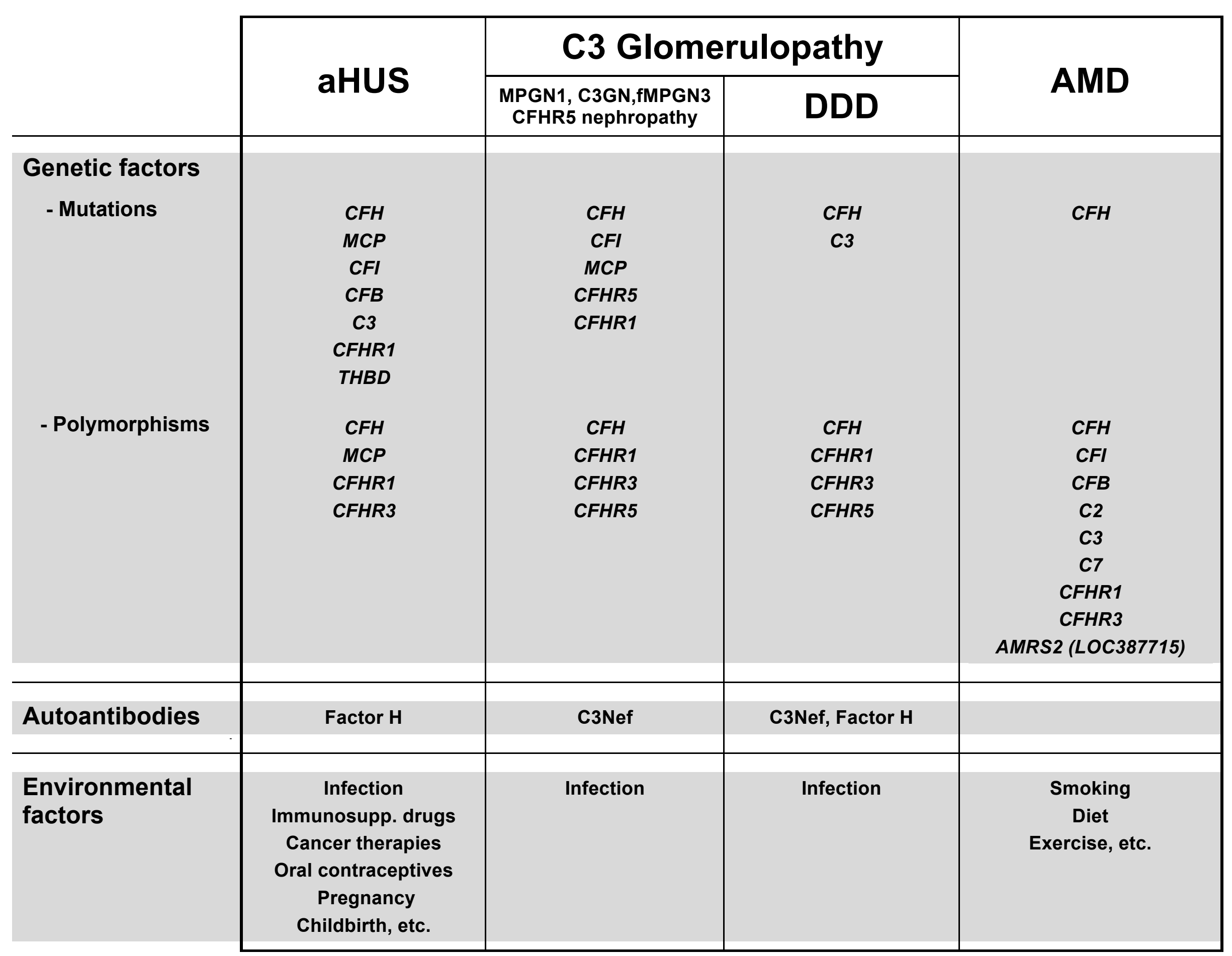


TABLE 2. CFHRs gene rearrangements associated with disease.

\begin{tabular}{|c|c|c|c|c|c|c|c|}
\hline \multicolumn{2}{|c|}{ Disease } & $\begin{array}{l}\text { Genetic } \\
\text { findings }\end{array}$ & Outcome & Significance & $\begin{array}{c}\text { Risk/ } \\
\text { Protection }\end{array}$ & Prevalence & Ref. \\
\hline \multicolumn{2}{|r|}{ aHUS } & $\begin{array}{c}\text { CFH::CFHR1 } \\
\text { hybrid genes } \\
\text { CFH::CFHR3 } \\
\text { hybrid gene } \\
\text { DelCFHR3-CFHR1 } \\
\text { DelCFHR1-CFHR4 } \\
\text { CFHR*B }\end{array}$ & $\begin{array}{l}\text { Substitution of the C-terminal } \\
\text { SCRs of fH for those in FHR-1. } \\
\text { Substitution of the last C- } \\
\text { terminal SCR20 of fH for the } \\
\text { whole FHR-3. } \\
\text { Loss of FHR-3 and FHR-1. } \\
\text { Loss of FHR-1 and FHR-4. } \\
\text { Allelic variant in which FHR-1 } \\
\text { SCR3 is identical to fH SCR18. }\end{array}$ & $\begin{array}{l}\text { Loss of complement } \\
\text { regulation at cell surfaces. } \\
\text { Loss of complement } \\
\text { regulation at cell surfaces } \\
\text { Associated with auto anti } \\
\text { fH antibodies impairing } \\
\text { cell surface regulation. } \\
\text { Unknown }\end{array}$ & $\mathrm{R}$ & $\begin{array}{l}\text { Several } \\
\text { unrelated cases } \\
\text { described } \\
\text { Very rare } \\
\text { Common } \\
\text { Common }\end{array}$ & $\begin{array}{l}\text { (Venables et al., 2006) } \\
\text { (Francis et al., 2012) } \\
\text { (Abarrategui-Garrido et } \\
\text { al., 2009; Moore et al., } \\
\text { 2010; Zipfel et al., 2007) } \\
\text { (Abarrategui-Garrido et } \\
\text { al., 2009) }\end{array}$ \\
\hline \multirow{3}{*}{ ア } & DDD & DupCFHR1 & $\begin{array}{l}\text { Mutant FHR-1 with } \\
\text { SCR123412345 }\end{array}$ & Unknown & $\mathrm{R}$ & Very rare & $\begin{array}{l}\text { (Abarrategui-Garrido et } \\
\text { al., 2010) }\end{array}$ \\
\hline & C3-GN & $\begin{array}{l}\text { CFHR3::CFHR1 } \\
\text { hybrid gene }\end{array}$ & $\begin{array}{l}\text { Hybrid protein containing } \\
\text { SCR } 1-2 \text { of FHR- } 3 \text { followed by } \\
\text { the whole FHR- } 1 \text { molecule. }\end{array}$ & Unknown & $\mathrm{R}$ & Very rare & (Malik et al., 2012) \\
\hline & $\begin{array}{c}\text { FHR5 } \\
\text { Nephropathy }\end{array}$ & DupCFHR5 & $\begin{array}{l}\text { Mutant FHR-5 with } \\
\text { SCR12123456789 }\end{array}$ & Unknown & $\mathrm{R}$ & $\begin{array}{l}\text { Several related } \\
\text { cases described }\end{array}$ & (Gale et al., 2010) \\
\hline \multicolumn{2}{|r|}{ AMD } & $\begin{array}{c}\text { DelCFHR3-CFHR1 } \\
\text { CFHR*A }\end{array}$ & $\begin{array}{l}\text { Loss of FHR-3 and FHR-1. } \\
\text { Allelic variant in which FHR-1 } \\
\text { SCR3 differs from fH SCR18 in } \\
\text { three amino acids. }\end{array}$ & $\begin{array}{l}\text { Unknown } \\
\text { Unknown }\end{array}$ & $\begin{array}{l}\mathrm{P} \\
\mathrm{R}\end{array}$ & $\begin{array}{l}\text { Common } \\
\text { Common }\end{array}$ & $\begin{array}{l}\text { (Hughes et al., 2006) } \\
\text { (Martinez-Barricarte et } \\
\text { al., 2012) }\end{array}$ \\
\hline & SLE & DelCFHR3-CFHR1 & Loss of FHR-3 and FHR- 1 . & Unknown & $\mathrm{R}$ & Common & (Zhao et al., 2011) \\
\hline
\end{tabular}




\section{*Detailed Response to Reviewers}

We have revised the manuscript in response to the helpful comments of the reviewers. We have updated figure 2 to include recently described mutations. We have replaced Figure 4 with a modified, clearer version, we have added text in several places (highlighted in submitted Ms) to address omissions noted in review. We have added four additional references in response to reviewer comments. 